Universidade de Brasília

Faculdade de Economia, Administração, Contabilidade e Ciência da Informação e Documentação Programa de Pós-Graduação em Administração

Curso Especialização em Gestão de Pessoas

FERNANDA CARNEIRO DE ANDRADE LIMA

IDENTIFICAÇÃO DE COMPETÊNCIAS NECESSÁRIAS AOS PROFISSIONAIS FORMULADORES DE POLÍTICAS PÚBLICAS DA SECRETARIA DE TURISMO DE PERNAMBUCO 
Universidade de Brasília

Faculdade de Economia, Administração, Contabilidade e Ciência da Informação e Documentação Programa de Pós-Graduação em Administração

Curso Especialização em Gestão de Pessoas

FERNANDA CARNEIRO DE ANDRADE LIMA

\section{IDENTIFICAÇÃO DE COMPETÊNCIAS NECESSÁRIAS AOS PROFISSIONAIS FORMULADORES DE POLÍTICAS PÚBLICAS DA SECRETARIA DE TURISMO DE PERNAMBUCO}

Projeto de monografia apresentado ao Programa de Pós-Graduação, da Faculdade de Economia, Administração, Contabilidade e Ciência da Informação e Documentação (FACE), da Universidade de Brasília, como requisito parcial à obtenção do grau de Especialista em Gestão de Pessoas.

Orientadora $\operatorname{Prof}^{\mathfrak{a}}$ Dr $^{\mathrm{a}}$. Catarina Cecília Odelius 


\section{AGRADECIMENTOS}

Agradeço a Deus e à Virgem Maria que através do amor incondicional, proporcionaram-me momentos de crescimento pessoal e profissional. Sem Eles nada seria possível.

À minha família, por tudo que representa em minha vida. Agradeço a compreensão de minha ausência em ocasiões especiais, a grande paciência diante de meu stresse e o enorme apoio em todos os momentos. Amo vocês!

À minha orientadora, Prof ${ }^{a}$. Dr. ${ }^{a}$ Catarina Odelius, pela atenção dedicada, pelas sugestões e pelas intervenções necessárias à finalização desta pesquisa.

A Carla Borba e a Roberta Jaroslavsky, que forneceram informações valiosas sobre a Secretaria de Turismo de Pernambuco, auxiliando imensamente no desenvolvimento da pesquisa.

A meus amigos de coração, que sempre estiveram presentes com uma palavra de apoio e que também compreenderam minhas ausências.

Ao corpo docente e aos funcionários do Curso de Especialização em Gestão de Pessoas III, pelas inúmeras lições profissionais e pessoais apresentadas ao longo do curso.

Às minhas amigas Jussara, Learice, Kátia e Patrícia pelo companheirismo e pela amizade verdadeira desenvolvidos ao longo do curso.

A todos, meus sinceros agradecimentos, reconhecimento e amizade! 
"Vem, vamos embora / Que esperar não é saber / Quem sabe faz a hora / Não espera acontecer" Geraldo Vandré 


\section{RESUMO}

A atividade turística, quando bem planejada, dentro de um modelo adequado de execução, onde a comunidade, os turistas, os profissionais do setor, as empresas privadas e o setor público participam do processo, proporciona o desenvolvimento sustentável de uma localidade, de uma região e de um país. Diante deste contexto, faz-se mister a ênfase na identificação das competências necessárias ao perfil dos profissionais que irão definir e executar as políticas públicas do turismo. Diversas empresas têm recorrido à utilização de modelos de gestão, baseados em conceitos como competências e desempenho, para planejar, captar, desenvolver e avaliar, nos diferentes níveis da organização, as competências necessárias à consecução de seus objetivos. A presente pesquisa tem como objetivos identificar as competências necessárias aos profissionais formuladores de políticas públicas da Secretaria de Turismo de Pernambuco (Setur), bem como verificar o grau de importância e o grau de domínio, por parte destes profissionais, em relação às competências identificadas. Para tanto, utilizou-se as técnicas de entrevista individual - realizada com uma pessoa-chave da organização, no intuito de elencar as competências necessárias aos referidos profissionais. A utilização desta metodologia resultou na identificação de 48 competências, entre conhecimentos, habilidades e atitudes. A outra técnica utilizada foi o questionário fechado, com as 48 competências identificadas previamente, que foi aplicado junto aos 7 profissionais formuladores de políticas públicas da Setur, onde se verificou o grau de importância e o grau de domínio das competências identificadas. A identificação, bem como a verificação do grau de importância e do grau de domínio destas competências, poderão servir para o planejamento de ações de treinamento e desenvolvimento, pessoal e profissional, por parte da organização e para os próprios profissionais reconhecerem as demandas da atividade que executam, proporcionando melhores resultados e desempenhos.

Palavras-chave: Competências. Identificação de competências. Políticas públicas. Turismo. 


\section{LISTA DE QUADROS}

Quadro 1 - Recursos Humanos na Organização do futuro por tendências atuais.............14

Quadro 2 - Conhecimentos identificados...................................................................................34

Quadro 3 - Habilidades identificadas........................................................................35

Quadro 4 - Atitudes identificadas.......................................................................................36 


\section{LISTA DE TABELAS}

Tabela 1 - Distribuição do grau de importância dos conhecimentos identificados...........37

Tabela 2 - Distribuição do grau de domínio dos conhecimentos identificados...................38

Tabela 3 - Média e desvio-padrão do grau de importância dos conhecimentos

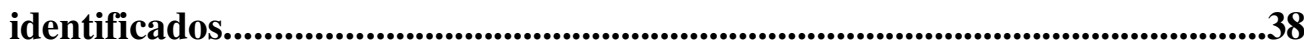

Tabela 4 - Média e desvio-padrão do grau de domínio dos conhecimentos

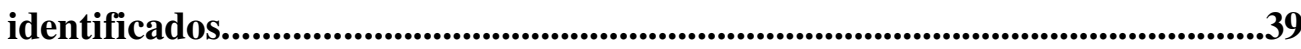

Tabela 5 - Distribuição do grau de importância das habilidades identificadas.................45

Tabela 6 - Distribuição do grau de domínio das habilidades identificadas........................46

Tabela 7 - Média e desvio-padrão do grau de importância das habilidades identificadas.

Tabela 8 - Média e desvio-padrão do grau de domínio das habilidades identificadas.....................................................................................................................48

Tabela 9 - Distribuição do grau de importância das atitudes identificadas.......................54

Tabela 10 - Distribuição do grau de domínio das atitudes identificadas..........................55

Tabela 11 - Média e desvio-padrão do grau de importância das atitudes identificadas......................................................................................................5

Tabela 12 - Média e desvio-padrão do grau de domínio das atitudes identificadas. 


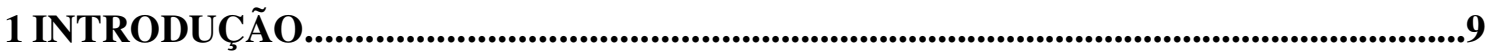

1.1 Contexto e Problema...................................................................................................9

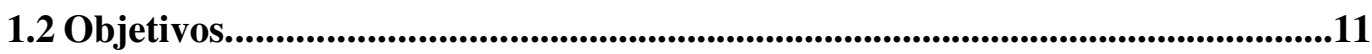

1.2.1 Objetivo Geral...................................................................................................11

1.2.2 Objetivos Específicos....................................................................11

1.3 Justificativa e Relevância.....................................................................................................11

2 MARCO TEÓRICO..........................................................................................................13

2.1 Gestão de pessoas e gestão por competências........................................................13

2.1.1 Gestão por competências.......................................................................15

2.1.2 Evolução do conceito de competências...............................................17

2.1.3 Nível de complexidade ligada à competência.....................................19

2.2 Competências individuais e organizacionais........................................................20

2.2.1 Competências individuais......................................................................21

2.2.2 Competências organizacionais.................................................................22

2.3 Mapeamento e identificação de competências.....................................................23

2.3.1 Técnicas de identificação de competências.............................................24

2.4 Turismo: definição e características.......................................................................25

2.5 Atuação e competências de formuladores de políticas públicas........................26

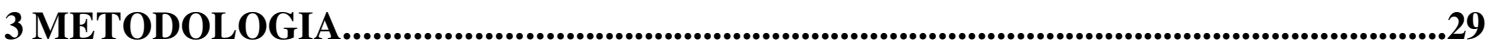

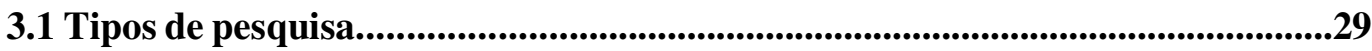

3.2 Contexto da pesquisa: objeto de análise.................................................................30

3.3 População e Amostra.................................................................................................30

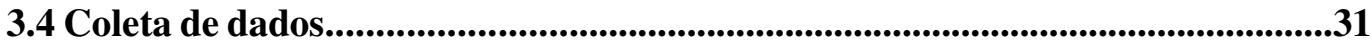

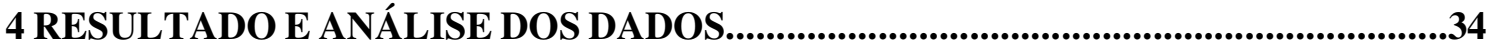

4.1 Conhecimentos.....................................................................................................................37

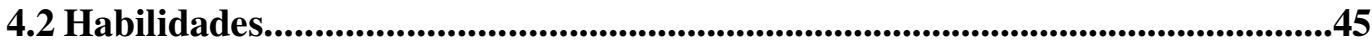

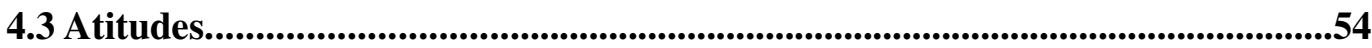

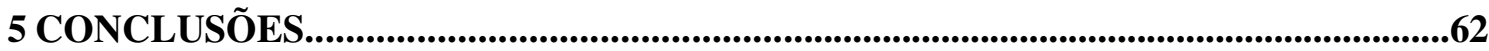

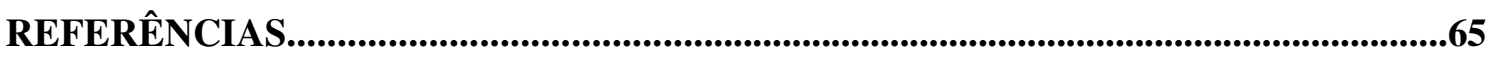

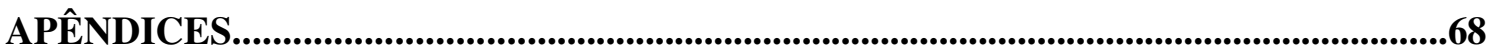




\section{INTRODUÇÃO}

\subsection{Contexto e Problema}

O Brasil é um lugar único por sua diversidade e por sua riqueza cultural, natural, econômica e histórica. Esta característica faz do país um ambiente com numerosos atrativos turísticos, obtendo na diversidade o principal instrumento de potencialização da atividade.

Ao longo dos anos, a atividade turística vem se destacando como uma importante atividade econômica em todo o mundo. No entanto, não se pode resumir o turismo como fator puramente econômico, mas também como um elemento de resgate histórico em defesa da valorização da cultura local, contribuindo, assim, para o desenvolvimento da comunidade.

A atividade turística é importante para qualquer economia, seja ela nacional, regional ou local, pois o deslocamento constante de pessoas aumenta o consumo, motiva a diversidade de produção de bens e serviços, possibilita o lucro e a geração de emprego e renda.

Sendo assim, o Turismo, pela natureza de suas atividades e pela dinâmica de seu crescimento, é um dos segmentos da economia que pode minimizar de forma abrangente e de maneira rápida as desigualdades sociais do país, visto que, quando bem planejado, dentro de um modelo adequado de execução, onde as comunidades, os turistas, os profissionais do setor, as empresas privadas e o setor público participam do processo, a atividade proporciona o desenvolvimento sustentável da localidade, de região e do país (BENI, 2001).

Estas características tornam ainda mais importante a formulação de políticas públicas que dêem sustentação ao setor. Barretto, Burgos e Frenkel (2003) explicam que, no Turismo, o papel das políticas públicas, caracterizadas pelas ações do Estado pautadas pelo interesse geral da sociedade, deve ser o de proporcionar o desenvolvimento harmônico da atividade. Assim, cabe ao Estado construir a infra-estrutura de acesso e a infra-estrutura básica urbana, além de prover de uma superestrutura jurídico-administrativa que planeje e controle, de maneira sistêmica e sustentável, o turismo como atividade sócio-econômica e cultural.

De acordo com Brandão e Guimarães (2001), a sociedade contemporânea passa por um período de significativas transformações sociais, políticas, econômicas e culturais, que ocasionam um processo de reestruturação produtiva. Nas organizações, o impacto dessa reestruturação materializa-se através de processos e técnicas de racionalização organizacional, que incorporam, ao ambiente empresarial, novas tecnologias e novos modelos de gestão. 
Ainda segundo os autores, configura-se como desafio às organizações desenvolver e utilizar instrumentos de gestão que lhes garantam competitividade atual e futura. As propostas para obtenção de vantagem competitiva convergem em um mesmo direcionamento, por meio de tecnologias e modelos de gestão que visem à gestão estratégica de recursos humanos, à gestão por competências, à acumulação do saber e à gestão do capital intelectual. Mas como identificar as competências necessárias aos profissionais formuladores de políticas públicas?

Diante deste contexto, para os autores, percebe-se a ênfase nas pessoas como recurso determinante do sucesso organizacional, uma vez que a busca pela competitividade determina que as empresas contem com profissionais altamente capacitados e aptos a enfrentar as ameaças e a captar as oportunidades existentes no mercado. Assim, o modelo de gestão por competências aparece como um instrumento eficiente no processo de gestão de pessoas.

Por isso, a identificação das competências necessárias aos profissionais formuladores de políticas públicas da Secretaria de Turismo de Pernambuco constitui o eixo central deste estudo.

Esta monografia está estruturada em cinco capítulos. Na introdução, são expostos o contexto, os objetivos, geral e específicos e a justificativa da relevância do assunto. No segundo capítulo, é realizada uma revisão de literatura iniciada com a gestão de pessoas atrelada à gestão por competências, bem como acerca dos conceitos de competências, individuais e organizacionais, por meio de diferentes abordagens. Também é apresentado o modelo de gestão por competências e algumas técnicas de como identificá-las. O marco teórico ainda discorre sobre a atividade turística, com definições e características, e sobre as atribuições dos profissionais formuladores de políticas públicas. Sendo assim, este capítulo procura fundamentar a principal base conceitual sobre o assunto desenvolvido no decorrer da pesquisa. Já o terceiro capítulo, que é a metodologia, buscou discorrer sobre os métodos e técnicas utilizados para a realização desta monografia e também apresentar e caracterizar a organização estudada. No quarto capítulo, constarão os resultados e a análise dos dados coletados na pesquisa. Por fim, são apresentadas as conclusões e algumas sugestões extraídas da análise dos dados estudados. 


\subsection{Objetivos}

\subsubsection{Objetivo Geral}

O objetivo geral desta pesquisa é identificar as competências necessárias aos profissionais formuladores das políticas públicas do setor de turismo, que atuam na Secretaria de Turismo de Pernambuco.

\subsubsection{Objetivos Específicos}

- Identificar missão, objetivos e desafios a serem enfrentados pela Secretaria de Turismo de Pernambuco - SETUR;

- Analisar as competências necessárias aos profissionais formuladores das políticas públicos do setor de turismo;

- Verificar o grau de importância e domínio das competências destes profissionais do turismo;

- Identificar possíveis lacunas entre as competências existentes e as necessárias à consecução dos objetivos organizacionais.

\subsection{Justificativa e Relevância}

Apesar de o Turismo ser uma das atividades econômicas mais dinâmicas e com taxas de crescimentos mais elevadas, comparando-se com outros setores e atividades, verifica-se a ausência de qualificação profissional do setor, tanto no âmbito gerencial quanto nas habilidades específicas operacionais (PIMENTA, 2006). Em relação à deficiência de qualificação profissional do setor, Dias (2006 apud PIMENTA, 2006) argumenta que o formidável crescimento da atividade turística não tem sido acompanhado de sua maior profissionalização e capacitação. O autor considera ainda que, em muitos casos, a atividade é considerada como marginal ou temporária, vivendo de períodos ora de picos, ora de diminuição de demanda. Esta situação gera insegurança para aqueles que buscam dedicar-se integramente a esse mercado de trabalho. Para que o Turismo seja reconhecido como atividade primordial e essencial no desenvolvimento das localidades, os formuladores de políticas públicas devem, de acordo com Gunn (1988), preocuparem-se com a influência do ambiente externo e com o relacionamento bidirecional entre os vários componentes da 
atividade turística: ambientes político, econômico, físico, natural e cultural; atrações; rede de transportes; serviços e facilidades (hospedagem, alimentação); direção da informação; e com os próprios turistas. Assim, o formulador deve estar atento ao caráter interdependente do Turismo, visto que a atividade envolve vários atores (turistas, comunidade, profissionais do trade) e vários contextos. Corroborando com o autor, Cooper et. al. (2001) explicitam a necessidade de reciprocidade e de interação entre as organizações turísticas e o Governo, sendo, para este, essencial o desenvolvimento de competências organizacionais e individuais que promovam e fomentem o Turismo.

Para Dutra (2004), existe uma relação íntima entre competências organizacionais e individuais e o estabelecimento das competências individuais deve estar vinculado à reflexão sobre as competências organizacionais, uma vez que é mútua a influência de uma e de outras.

Corroborando com esta idéia, Fleury e Fleury (2004) expõem dois grandes desafios para as organizações em termos de desenvolvimento de um modelo de gestão por competências:

- Alinhar, de forma efetiva, as competências individuais às competências organizacionais e às estratégias de negócio das empresas; e

- Desenvolver nas pessoas aquelas competências que não agreguem valor apenas à organização, mas que também agreguem valor ao indivíduo, possibilitando o incremento de modelos mais flexíveis, com espaço para o aprimoramento do ser humano.

Para que o alinhamento entre as competências ocorra é necessário realizar o mapeamento de competências. De acordo com Ienaga (1998 apud BRANDÃO; BAHRY, 2005), o mapeamento de competências tem como objetivo identificar a discrepância entre as competências necessárias para o alcance da estratégia corporativa e competências existentes na organização.

Com base nesta premissa, justifica-se a importância deste estudo, principalmente pela necessidade de a atividade possuir profissionais qualificados, atualizados e capacitados, que saibam como agir diante de um contexto complexo e multidisciplinar. Como o crescimento significativo da atividade turística ocorreu relativamente há pouco tempo, existe uma lacuna entre a demanda do mercado e a formação dos profissionais. Diante desta situação, estudos que visam à resolução deste impasse são de extrema relevância para os órgãos e organizações que atuam no setor, como por exemplo, a Secretaria de Turismo de Pernambuco, objeto de estudo desta pesquisa, cujas atribuições são, prioritariamente, planejar, fomentar e executar a política de desenvolvimento do Turismo no Estado. 


\section{MARCO TEÓRICO}

Nesta parte do trabalho, realizou-se uma revisão de literatura a respeito da gestão de pessoas atrelada à gestão por competências e a respeito da evolução do conceito de competências, relacionado à prática de gestão de pessoas. Também são apresentadas algumas definições de competências, de acordo com o entendimento de diversos autores, onde foram elencados os conceitos de competências individuais e organizacionais. Este capítulo também discorre sobre a dinâmica do modelo de gestão por competências e algumas técnicas de identificação das mesmas. Por fim, são expostos conceitos e características relativos ao turismo, bem como são apresentadas atribuições dos formuladores de políticas públicas na área de turismo.

\subsection{Gestão de Pessoas e Gestão por Competências}

De acordo com os autores Zabot e Silva (2002, p.58), “a tecnologia da informação e a Gestão por Competências têm sido consideradas como um dos principais fatores responsáveis pelo sucesso das organizações, tanto no nível de sobrevivência, quanto ao aumento de competitividade".

Ainda de acordo com os autores, neste mundo de rápidas transformações, muitas empresas têm buscado meios e ações estratégicas para garantir a sobrevivência no mercado. A preocupação com a qualidade, produtividade e competitividade tem sido, cada vez mais, uma constante na vida das organizações. Essa preocupação exige a predisposição por parte das pessoas e das organizações de permanente aprendizado, visando acompanhar esse turbulento cenário de mudanças.

Cada vez mais é preciso que haja o reconhecimento da necessidade de profissionais qualificados, preparados para enfrentar a acirrada competitividade, dispostos a "aprender a aprender" e a oportunizar o aprendizado a outras pessoas que fazem parte da organização. Para isso, salienta-se a grande ênfase que tem sido dada às práticas de gestão de pessoas, alinhadas a novos formatos de aprendizagem e desempenho, buscando-se instituir uma cultura de aprendizagem nas organizações.

Assim, as práticas de gerenciamento das pessoas que atuam nos mais diversos setores são consideradas necessidade imperante, visto ser a forma mais rápida e eficaz para alavancar e conduzir o processo de mudanças e aprendizagem nas organizações. 
De um lado, destaca-se a ênfase à implementação de novos sistemas de gestão, no qual o ser humano passa a ser o foco principal na administração das organizações. De outro lado, observa-se a grande distância que existe entre o discurso (aquilo que se quer) e a ação (aquilo que realmente se faz), o que exige das organizações "novas maneiras de pensar e fazer RH" (Ulrich, 1998, p. 233). Para esse mesmo autor, organizações bem sucedidas serão aquelas capazes de transformar, rapidamente, estratégias em ação, de gerenciar processos de forma inteligente, de maximizar o compromisso e a colaboração do funcionário e de criar condições para uma mudança consistente.

Essas mudanças, por sua vez, impulsionam o questionamento de paradigmas, provocando nas pessoas que ocupam funções gerenciais um estado de abertura e flexibilidade para (re)discutir, (re)ver e (re)criar uma nova forma de pensar e agir em relação à gestão de pessoas (CHIAVENATO, 2002).

Dentro desse panorama de transformações, Motta (1998) salienta a importância das pessoas como diferencial competitivo e sintetiza as principais mudanças na forma de gerenciá-las (Quadro 1). O quadro 1 reforça a descentralização nos procedimentos da gestão de pessoas e a importância do autodesenvolvimento do indivíduo através de contínuo aprendizado.

Quadro 1 - Recursos Humanos ${ }^{1}$ na Organização do futuro por tendências atuais

\begin{tabular}{|c|c|c|}
\hline FATORES & PASSADO = PRESENTE & PRESENTE = FUTURO \\
\hline Concepção do funcionário & Recurso humano & Pessoa talentosa \\
\hline Carreira e Progresso & $\begin{array}{l}\text { Crescimento no emprego: perseguir } \\
\text { alternativas conhecidas. }\end{array}$ & $\begin{array}{c}\text { Aumento da empregabilidade: criar } \\
\text { o próprio futuro. }\end{array}$ \\
\hline Avaliação & Chefias & Aberta e coletiva \\
\hline Formação e Conhecimento & $\begin{array}{c}\text { Aprender o necessário: a empresa } \\
\text { indica }\end{array}$ & $\begin{array}{l}\text { Autodesenvolvimento (habilidades } \\
\text { múltiplas): o funcionário escolhe }\end{array}$ \\
\hline Remuneração & $\begin{array}{c}\text { Variável: critérios individuais e } \\
\text { grupais; incentivos financeiros e } \\
\text { materiais }\end{array}$ & $\begin{array}{c}\text { Variável: incentivos e benefícios } \\
\text { adaptados às expectativas } \\
\text { individuais }\end{array}$ \\
\hline Gestão de recursos humanos & Centralizada: órgão especializado & $\begin{array}{c}\text { Descentralizada: repartida pelos } \\
\text { setores empresariais }\end{array}$ \\
\hline Cultura da gestão das pessoas & $\begin{array}{c}\text { Impessoalidade, exploração, estima } \\
\text { e benevolência }\end{array}$ & $\begin{array}{c}\text { Pessoalidades, desenvolvimento e } \\
\text { retribuição }\end{array}$ \\
\hline
\end{tabular}

Fonte: MOTTA, 1998, p.101

\footnotetext{
1 Entendemos que o termo "Gestão de Pessoas" é mais adequado e apropriado, porém mantivemos a
} nomenclatura original proposta pelo autor. 
Em suma, a gestão de pessoas sofreu muitas transformações nos últimos vinte anos, conforme afirma Dutra (2001, p. 25-26):

Alteração no perfil das pessoas exigidas pelas empresas. Ao perfil obediente e disciplinado prefere-se um perfil autônomo e empreendedor. A mudança no padrão de emergência gerou a necessidade de uma cultura organizacional que estimulasse e apoiasse a iniciativa individual, a criatividade e a busca autônoma de resultados para a empresa ou negócio.

Deslocamento do foco da gestão de pessoas por meio do controle para o foco por meio do desenvolvimento. A marca dos sistemas tradicionais de gestão de pessoas, inspirada no paradigma fordista e taylorista de administração, é o controle das pessoas. Segundo esse paradigma, os indivíduos são controláveis, portanto, espera-se deles uma postura passiva. Hoje, há uma grande pressão para que a gestão de pessoas seja orientada para a idéia de desenvolvimento mútuo. A empresa, ao se desenvolver, desenvolve as pessoas, e estas, ao se desenvolverem, fazem o mesmo com a organização. A pessoa é vista como gestora de sua relação com a empresa, bem como do seu desenvolvimento profissional.

Maior participação das pessoas no sucesso do negócio ou da empresa. O comprometimento integral dos indivíduos com a organização ou negócio mobiliza não somente os músculos e parte da inteligência, mas todo o seu potencial criador, sua intuição, sua capacidade de interpretar o contexto e de agir sobre ele, gerando vantagens competitivas únicas. As pessoas são depositárias do patrimônio intelectual da empresa, bem como da capacidade e da agilidade de resposta da organização aos estímulos do ambiente e ainda da capacidade de visualização e explicação de oportunidades de negócios.

É importante observar que as transformações não acompanharam os conceitos e ferramentas da gestão de pessoas, pois as formas como as organizações gerenciam as pessoas, muitas vezes, não refletem a real necessidade da organização, ou seja, as organizações devem mudar a forma de gerir pessoas, procurando por um modelo de gestão confiável para substituir o modelo tradicional.

\subsubsection{Gestão por competências}

Entende-se competência como um conjunto integrado de conhecimentos, habilidades e atitudes, que permite às pessoas desenvolver atribuições e responsabilidades, encarando a competência como forma instrumental. Porém, as pessoas possuem várias habilidades, conhecimentos e atitudes, que beneficiam a empresa, na qual o indivíduo é avaliado e analisado para poder ser admitido e promovido, conforme a capacidade de sua função na organização (DUTRA, 2001).

Neste sentido, de acordo com Guimarães, Bruno-Faria e Brandão (2006), diversas empresas têm recorrido à utilização de modelos de gestão, baseados em conceitos como competências e desempenho, para planejar, captar, desenvolver e avaliar, nos diferentes níveis 
da organização (individual, grupal e organizacional), as competências necessárias à consecução de seus objetivos.

Para identificar as principais etapas do modelo de gestão por competências, Brandão e Guimarães (2001) elaboraram um diagrama (Figura 1), onde propõem que a primeira etapa seja constituída da formulação da estratégia organizacional, seguida da definição da missão, da visão de futuro e dos objetivos organizacionais. Carbone et. al. (2006), explicam que missão organizacional é o propósito principal pelo qual uma organização existe; visão referese ao estado futuro desejado pela organização e; objetivos estratégicos representam a situação a ser buscada pela organização em um dado período de tempo. Assim, em razão dos objetivos estratégicos estabelecidos, é possível definir indicadores de desempenho no nível corporativo, bem como identificar as competências necessárias à consecução do desempenho esperado.

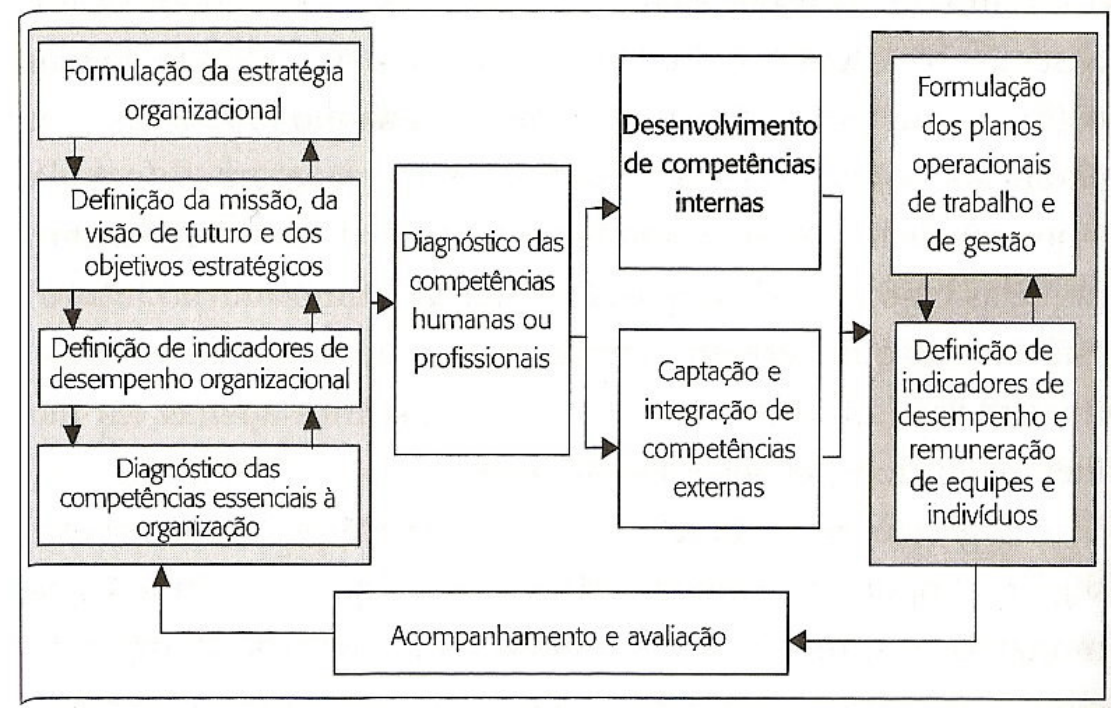

Figura 1 - Modelo de Gestão por Competências

Fonte: Adaptado de Brandão; Guimarães. (2001).

De acordo com o modelo proposto por Brandão e Guimarães (2001), a próxima etapa consiste na realização do diagnóstico ou mapeamento das competências (individuais e organizacionais), onde se identifica a lacuna existente entre as competências necessárias ao alcance das estratégias organizacionais e as competências disponíveis na organização (Figura 2). Carbone et. al. (2006) ressaltam que é de fundamental importância a captação e o desenvolvimento de competências, visto que na ausência destas ações, a lacuna entre as competências tende a crescer. 


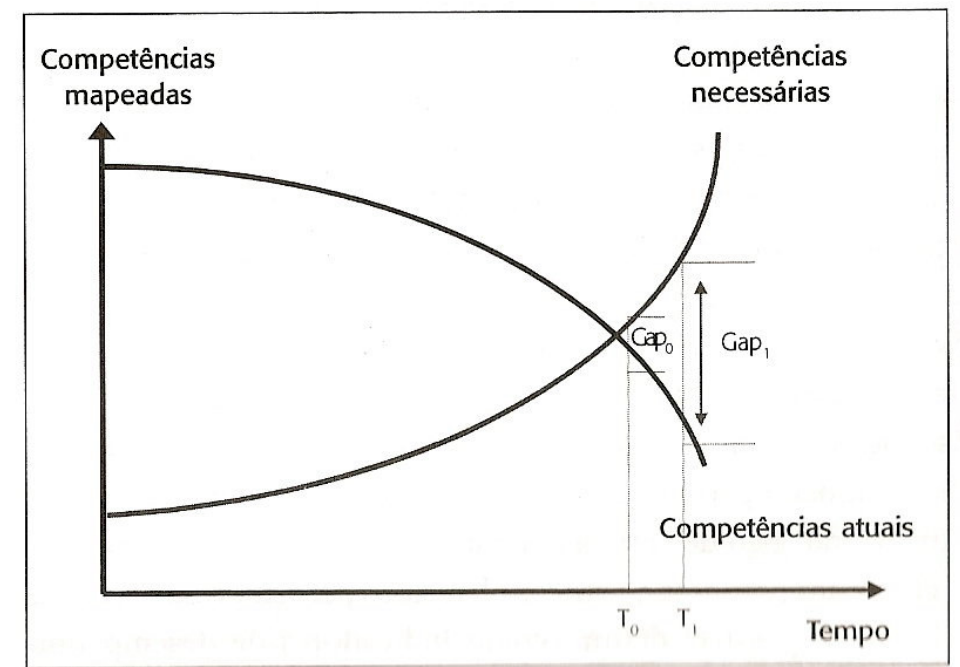

Figura 2 - Identificação da lacuna de competências

Fonte: Adaptado de Ienaga (1998 apud BRANDÃO; GUIMARÃES, 2001).

\subsubsection{Evolução do conceito de competências}

O conceito de competência é central em inúmeras abordagens utilizadas na psicologia organizacional e do trabalho, desde as que focalizam fenômenos como a inteligência em seleção de pessoal, passando por aquelas que se preocupam com motivação humana no trabalho, até as que procuram compreender como se dá a aprendizagem em Treinamento, Desenvolvimento e Educação - TD\&E. A centralidade do conceito de competência é ainda mais evidente quando, atualmente, são discutidos métodos de diagnósticos de necessidades em TD\&E (LIMA; BORGES-ANDRADE, 2006).

O estudo do conceito "competência" não é recente. Trata-se de uma idéia consideravelmente antiga, porém (re)conceituada e (re)valorizada atualmente, em virtude de fatores como os processos de reestruturação produtiva, a intensificação das instabilidades e imprevisibilidades das situações econômicas, políticas, organizacionais e de mercado e as mudanças nas características do mercado de trabalho, resultantes, em especial, dos processos de globalização (FLEURY; FLEURY, 2004).

No fim da Idade Média, de acordo com Isambert-Jamati (2001 apud BRUNO-FARIA; BRANDÃO, 2003), a palavra competência era concernente à linguagem jurídica, relativa à atribuição de competência a uma pessoa ou a um tribunal para apreciar e julgar determinadas questões. Assim, o termo designava o reconhecimento social sobre a capacidade de alguém pronunciar-se acerca de um assunto específico. Da capacidade legal de um tribunal julgar alguma questão, o termo passou a ser entendido como capacidade de realizar determinada tarefa. No uso não-erudito, a noção de competência supõe que, havendo uma dada tarefa a ser 
realizada, tarefa essa que exija uma atividade intelectual e uma habilidade particular adquirida, existirão especialistas que têm a possibilidade de cumpri-la adequadamente e aqueles que não a têm, sendo essa diferença claramente identificável. Portanto, um indivíduo é competente ao ter sua capacidade reconhecida em dado assunto.

Segundo Santos (2001), no início do século XX, com o advento da Revolução Industrial e da Administração Científica, as empresas procuravam aperfeiçoar em seus funcionários as habilidades requeridas para a execução de certas funções, baseando-se nos aspectos operacionais do trabalho e nas especificações do cargo. Diante desta ótica, a competência era entendida como um conjunto de conhecimentos e habilidades que capacitava uma pessoa a desempenhar certa função. Posteriormente, devido ao aumento da complexidade das relações de trabalho, as organizações passaram a considerar, no processo de desenvolvimento de seus empregados, também os aspectos de cunho sociais e atitudinais que compunham a realidade da tarefa. Assim, segundo o autor, houve o reconhecimento de que as pessoas não são competentes apenas nos fatores cognitivos, mas também no que se refere aos aspectos emocionais.

Após a consideração dos fatores emocionais, ocorreu a valorização das atitudes na construção do conceito de competência. Zarifian (1996 apud BRANDÃO; GUIMARÃES, 2001), ao definir competência, faz alusão à metacognição e às atitudes relacionadas ao trabalho, fundamentando-se na premissa de que, em um ambiente dinâmico e competitivo, não é possível considerar o trabalho como um conjunto de tarefas ou atividades pré-definidas e estáticas. Para esse autor, competência significa "assumir responsabilidades frente a situações de trabalho complexas [aliadas] (...) ao exercício sistemático de uma refletividade no trabalho" (ZARIFIAN, 1996, p. 5), permitindo ao profissional lidar com eventos inéditos, surpreendentes e de natureza singular.

A partir dos anos 90, de acordo com Dutra (2004), sobretudo em razão do processo de globalização e do grau de complexidade existente nas relações comerciais, a necessidade de as organizações agregarem valor aos produtos e serviços levou-as a procurar, de maneira mais veloz, respostas e alternativas para enfrentar as situações inusitadas e para aumentar a competitividade.

Corroborando com esta consideração, Brandão e Guimarães (2001) percebem a ênfase nas pessoas como recurso determinante do sucesso organizacional, uma vez que a busca pela competitividade determina que as empresas contem com profissionais altamente capacitados e aptos a enfrentar as ameaças e a captar as oportunidades existentes no mercado. Assim, modelo de gestão por competências aparece como forte tendência na gestão de pessoas. 
Atualmente, existem diversas maneiras de entender e interpretar o conceito de competência. Para Brandão (2007) competência constitui, portanto, um conceito complexo e multifacetado, que pode ser analisado sob diferentes perspectivas e está sujeito a ambigüidades.

Para Le Bortef (1995 apud DUTRA; HIPÓLITO; SILVA, 2000), por exemplo, a competência não é estado ou conhecimento que se tem nem, tampouco, é resultado de treinamento. Competência caracteriza-se em colocar em prática o que se sabe dentro de um contexto específico, marcado geralmente pelas relações de trabalho, pela cultura da empresa, pelos imprevistos, pelas limitações de tempo e de recursos. Para o entendimento de Dutra, Hipólito e Silva (2000), competência é a capacidade de uma pessoa em gerar resultados dentro dos objetivos organizacionais e estratégicos.

Sparrow e Bognanno (1994 apud BRANDÃO; GUIMARÃES, 2001) fazem referência a um repertório de atitudes que possibilitam ao profissional adaptar-se rapidamente a um ambiente cada vez mais instável e ter uma orientação para a inovação e à aprendizagem permanentes. Ainda de acordo com estes autores, competências representam atitudes identificadas como relevantes para a obtenção de alto desempenho em um trabalho específico ao longo de uma carreira profissional ou no contexto de uma estratégia corporativa.

De acordo com Durand (1999 apud CARDOSO FILHO, 2003), o desenvolvimento de competências dá-se por meio da aprendizagem individual e coletiva, envolvendo simultaneamente três dimensões: assimilação de conhecimentos, integração de habilidades e adoção de atitudes relevantes para um contexto organizacional específico ou para obtenção de alto desempenho no trabalho.

\subsubsection{Nível de complexidade ligada à competência}

É através da complexidade da competência que se avalia o processo de valorização das pessoas, através do mercado e o nível de associação de valor, conforme seu cargo e pelo grau hierárquico do indivíduo dentro da organização (DUTRA, 2001).

Ainda segundo o autor, na década de 90, houve grandes transformações, onde os sistemas de gestão tornaram-se mais eficientes, contribuindo para a valorização do indivíduo dentro de uma organização, e desenvolvendo a capacidade do indivíduo de assumir e de executar suas atribuições e responsabilidades em maior âmbito, estabelecendo uma ligação entre desenvolvimento e remuneração, pois as responsabilidades e atribuições aumentaram o grau de complexidade. 
Ressalta-se que é possível aumentar o nível de complexidade das atribuições e responsabilidades da pessoa sem alterar seu cargo na organização, obedecendo duas variáveis: necessidade das empresas e a competência do indivíduo (DUTRA, 2001).

Diante do exposto percebe-se que a relação entre o trabalho e o indivíduo exige que este encare sempre novos desafios, correspondendo de forma positiva a esta realidade.

De acordo com Rabaglio (2001), competência está associada com um bom desempenho, numa determinada tarefa. Ter competências para a realização de uma tarefa significa ter conhecimentos, habilidades e atitudes compatíveis com o desempenho dela e ser capaz de colocar esse potencial em prática sempre que for necessário.

Uma pessoa com esse perfil de competência possui um diferencial competitivo. Às vezes, muitas pessoas têm conhecimentos, porém nunca os colocou em prática. Isto quer dizer que não desenvolveu habilidades. Ou seja, o profissional possui habilidades e conhecimentos, porém falta desenvolver um comportamento compatível com a prática de seu trabalho.

\subsection{Competências individuais e organizacionais}

Para Guimarães, Bruno-Faria e Brandão (2006), o conceito de competência, quando aplicado à gestão de organizações, pode ser interpretado em dois níveis: macro e micro organizacional. No nível macro, relativo à organização como um todo, o suporte teórico do termo competência advém da economia e da administração, que tratam de competências críticas ou competências essenciais e procuram associá-las à competitividade das organizações. No que se refere ao nível micro, baseado na psicologia organizacional e do trabalho, a abordagem incide sobre a análise das relações entre aprendizagem, competência individual e comportamento organizacional. Portanto, de acordo com estes autores, é possível classificar as competências em organizacionais (próprias à organização como um todo) e individuais (relativas às pessoas).

Corroborando com essa afirmação, Dutra (2004) explica que o estabelecimento das competências individuais deve estar atrelado às competências organizacionais, devido à existência de uma mútua influência entre os recursos e valores de uma organização com conhecimentos, habilidades e atitudes desenvolvidos pelos indivíduos da mesma organização. 


\subsubsection{Competências individuais}

De acordo com Durand (1999 apud CARDOSO FILHO, 2003), o conceito de competência baseia-se em três dimensões:

I. Conhecimento: diz respeito ao saber acumulado pela pessoa ao longo da vida, correspondendo a uma série de informações assimiladas e estruturadas pelo indivíduo, que lhe permitem entender o mundo;

II. Habilidade: relaciona-se à capacidade de aplicar e fazer uso produtivo do conhecimento, utilizando-o em uma ação para o alcance de um objetivo específico;

III. Atitude: relaciona-se a aspectos sociais e afetivos associados ao trabalho, implicando um sentimento, uma emoção ou um grau de aceitação ou rejeição do indivíduo em relação aos outros.

Sob a perspectiva do desempenho humano no trabalho, seria possível definir competência individual não apenas como o conjunto de conhecimentos, habilidades e atitudes - CHAs - necessárias para exercer determinada atividade, mas também como o desempenho expresso pela pessoa em um determinado contexto, em termos de comportamentos e realizações decorrentes da mobilização dos CHAs no trabalho. Portanto, as competências individuais são entendidas como uma combinação sinérgica de conhecimentos, habilidades e atitudes, expressas pelo desempenho profissional, em determinado contexto ou estratégia organizacional, agregando valor às pessoas e às organizações (GUIMARÃES; BRUNOFARIA; BRANDÃO, 2006).

Para Zarifian (2001), o bom profissional incorpora competências ou aperfeiçoa aquelas que já domina, dentro do contexto e da vivência no ambiente de trabalho. Indivíduos capacitados estão constantemente modificando as competências e adquirindo novas formas de agir, de pensar e de posicionar-se em sua atividade profissional. As competências individuais, continua o autor, nem sempre se referem a um fazer, mas a um saber fazer. Os melhores profissionais não são os que executam todas as atividades que lhes são designadas, mas são aqueles que se antecipam aos problemas e que buscam alternativas para resolvê-los.

Segundo Murray (2003 apud LIMA; BORGES-ANDRADE, 2006), as competências pessoais englobam atributos, habilidades e comportamentos de pessoas para desempenhar uma função ou tarefa de um trabalho.

De acordo com Fleury e Fleury (2004), competência individual diz respeito à capacidade de o profissional em associar todas as suas qualidades pessoais, no intuito de 
alcançar o melhor desempenho, dentro de sua área de atuação: saber o que e por que se faz, saber desenvolver-se e propiciar o desenvolvimento dos outros, comprometer-se com os objetivos da organização, assumindo os riscos e as conseqüências de suas ações e conhecer e entender as atribuições da organização, a fim de identificar as oportunidades existentes no ambiente.

Segundo Carbone et. al. (2006), as competências humanas são reveladas quando as pessoas agem diante das situações profissionais com as quais se deparam e servem como ligação entre as condutas individuais e a estratégia organizacional. Assim, continuam os autores, a competência resulta da mobilização, por parte do indivíduo, de uma combinação de recursos ou insumos, gerando um resultado no trabalho, decorrente da aplicação simultânea das três dimensões da competência (conhecimentos, habilidades e atitudes).

\subsubsection{Competências organizacionais}

De acordo com Fleury e Fleury (2004), assim como os indivíduos desenvolvem competências percebidas como conjuntos de conhecimentos, habilidades e atitudes, as organizações também desenvolvem competências que contribuem para o desempenho de suas atividades de negócio, considerando-se tanto os conhecimentos adquiridos com a experiência da organização, como também os valores que a empresa defende e o processo de interação entre as pessoas que a compõem. A organização poderia ser vista, então, como um portfólio de competências.

Segundo Murray (2003 apud LIMA; BORGES-ANDRADE, 2006), competências organizacionais são definidas por processos, sistemas e práticas, que habilitam uma organização a transformar capacidades pessoais em competências organizacionais como um todo.

As competências organizacionais foram classificadas, por Lado e Wilson (1994 apud LIMA; BORGES-ANDRADE, 2006), em:

a. Competências de gestão: incluem as capacidades (dos líderes de uma organização) de articularem uma visão estratégica, comunicá-la a toda organização e capacitá-la a realizar essa visão. Os lideres, também, devem ser capazes de formar relações adequadas com o ambiente organizacional.

b. Competências de entrada: abarcam todos os recursos físicos, de capital, humanos, conhecimentos, habilidades e capacidades que permitem uma 
organização realizar os processos de geração de produtos e serviços de valor aos seus stakeholders.

c. Competências transformacionais: referem-se às capacidades organizacionais necessárias para converter entradas em saídas (produtos ou serviços). Estas capacidades incluem inovação, empreendedorismo, cultura e aprendizagem organizacional.

d. Competências de saída: englobam bens estratégicos organizacionais intangíveis e baseados em conhecimentos, associados ao valor dos produtos e serviços da organização para seus stakeholders.

Para Prahalad e Hamel (1990 apud CARBONE et. al, 2006), a competência organizacional é uma capacidade que permite a eficácia da organização na consecução de objetivos estratégicos. Ainda segundo os autores, competências organizacionais essenciais são atributos que conferem vantagem competitiva à organização e que são difíceis de serem imitados pela concorrência.

Em suma, de acordo com Von Krogh e Roos (1995 apud LIMA; BORGESANDRADE, 2006), uma importante característica das competências é que elas são dinâmicas. Para os autores, as competências evoluem por meio da interação entre a execução das tarefas e a aquisição de conhecimentos. Essa aquisição de conhecimentos pode ocorrer através da internalização de conhecimento explícito e formal ou por meio da aquisição derivada da própria solução da tarefa. De qualquer forma, as competências que interessam a uma organização são, elas mesmas, mutáveis ao longo do tempo.

\subsection{Mapeamento e identificação de competências}

Tendo em vista o caráter dinâmico das competências, existe a permanente necessidade de manter atualizado o rol das competências encontradas na organização, a fim de atingir os objetivos e a estratégia organizacionais. Neste sentido, afirmam Brandão e Bahry (2005), a gestão por competências vem sendo balizada como um modelo gerencial alternativo aos instrumentos comumente utilizados pelas organizações. Este modelo de mapeamento e identificação de competências, continuam os autores, visa, essencialmente, gerenciar a lacuna de competências, reduzindo a discrepância entre as competências necessárias à consecução dos objetivos e aquelas já disponíveis na organização. 
Guimarães e colaboradores (2001 apud GUIMARÃES; BRUNO-FARIA, BRANDÃO, 2006) utilizam a expressão "gestão de desempenho baseada em competências" para denominar o processo em que a organização, a partir de sua formulação estratégica (missão, visão de futuro, objetivos, metas), identifica a lacuna existente entre as competências (individuais e organizacionais) relevantes à consecução de seus objetivos e as competências internas disponíveis na organização. As etapas posteriores compreendem o planejamento, a seleção e o desenvolvimento de competências, que buscam a diminuição da referida lacuna. Segundo Durand (2000 apud GUIMARÃES; BRUNO-FARIA, BRANDÃO, 2006), a etapa do desenvolvimento de competências dá-se através da aprendizagem, de caráter individual ou coletivo, envolvendo a aquisição de conhecimentos, habilidades e atitudes relevantes aos propósitos da organização.

Para a realização deste mapeamento, a organização pode fazer uso de diversos métodos e técnicas de pesquisa social, os quais auxiliam na elaboração de um diagnóstico, permitindo não apenas a identificação da lacuna de competências, mas também o planejamento de ações de recrutamento, de seleção e de desenvolvimento profissional (BRANDÃO; BAHRY, 2005). Corroborando com esta assertiva, Guimarães, Bruno-Faria e Brandão (2006) esclarecem que não há uma maneira única e exclusiva para a descrição e identificação de competências em organizações e, portanto, a decisão a respeito sobre como descrevê-las faz parte do processo de mapeamento.

\subsubsection{Técnicas de identificação de competências}

Guimarães, Bruno-Faria e Brandão (2006) esclarecem que, para se identificar as competências organizacionais e individuais, faz-se mister conhecer a realidade da organização na qual se realiza o diagnóstico. Uma técnica de grande importância neste momento é a análise documental, visto que possibilita ao pesquisador compreender a estratégia da organização e suas características fundamentais, observadas em diferentes documentos, como estrutura organizacional, planejamento estratégico e plano diretor. Dos referidos documentos, são extraídas informações sobre a natureza das atividades exercidas na organização. Entretanto, continuam os autores, diversas informações acerca da realidade das organizações não se encontram nos documentos, mas sim nos relatos dos profissionais que atuam nesse contexto. Para isto, afirmam Carbone et. al. (2006), a entrevista individual caracteriza-se como outra técnica de pesquisa bastante utilizada no processo de mapeamento de 
competências, sendo comumente utilizada para identificar a percepção dos entrevistados com relação aos dados apurados na análise documental.

Frequentemente, nem o pesquisador nem os profissionais que são objetos de estudo possuem tempo para entrevistas individuais. Neste caso, uma técnica alternativa é a entrevista coletiva, também denominada grupo focal, onde o pesquisador atua como moderador, estimulando e coordenando a discussão entre os participantes (CARBONE ET. AL., 2006; GUIMARÃES; BRUNO-FARIA; BRANDÃO, 2006).

Outra técnica aplicada na identificação de competências é a observação. Esta técnica, de acordo com Carbone et. al. (2006), constitui-se em um exame detalhado do fenômeno ou objeto estudado. A observação pode ser do tipo participante, quando o pesquisador coloca-se no mesmo nível das pessoas que compõem o fenômeno do estudo, ou do tipo não participante, quando o observador não toma parte do objeto estudado, atuando apenas como um espectador do fenômeno (VIEGAS, 1999; MATTAR, 1996 apud CARBONE ET. AL., 2006).

De acordo com Guimarães, Bruno-Faria e Brandão (2006), as análises documentais, as entrevistas (individuais e coletivas) e a observação são, geralmente, utilizadas como fontes para elaboração dos itens que formam o instrumento quantitativo de identificação de competências, o questionário. Os autores ressaltam que, em pesquisa quantitativa, este instrumento de coleta de dados possui grande relevância. Neste caso, segundo Carbone et. al. (2006), o pesquisador identifica, por meio das técnicas previamente utilizadas, as competências supostamente relevantes para a organização. Posteriormente, edita e ordena tais competências, a fim de eliminar ambigüidades, irrelevâncias e duplicidades. Por fim, o pesquisador define a escala mais adequada para que os respondentes avaliem o grau de importância e o grau de domínio das competências identificadas.

$\mathrm{Na}$ presente pesquisa, serão utilizadas as técnicas de entrevista individual e questionário, posteriormente descritas no capítulo referente à metodologia.

\subsection{Turismo: definição e características}

Barretto (2003) explica que o turismo consiste no deslocamento de pessoas que, por diversas motivações, deixam temporariamente seu lugar de residência, visitando outros lugares, utilizando uma série de equipamentos e serviços especialmente implementados para esse tipo de visitação. A atividade dos turistas acontece durante o deslocamento e a permanência fora da sua residência. Os negócios turísticos são os realizados nos 
equipamentos ou durante a prestação de serviços que os turistas utilizam na preparação e na execução da sua atividade.

Para dar ênfase ao caráter sistêmico e global da atividade turística, a autora argumenta, ainda, que o processo da viagem começa no local de origem, quando os turistas se dirigem a uma agência de viagens ou a uma companhia de transportes para comprar um pacote turístico ou uma passagem, continuando quando os turistas chegam ao local de destino e utilizam transporte local, traslados, hospedagem, serviços de alimentação e diversão, lojas de suvenires, e termina apenas quando os turistas retornam a casa e levam seus filmes para revelação na loja do bairro.

Corroborando com esse conceito, a Organização Mundial de Turismo - OMT - (2001) define o turismo como as atividades que as pessoas realizam durante suas viagens e estadas em lugares diferentes ao seu entorno habitual, por um período consecutivo inferior a um ano, com finalidade de lazer, negócios ou outras. Sendo a atividade turística um conjunto complexo e dinâmico de inter-relações de diferentes fatores e atores, ela deve ser vista de forma sistemática, onde se distinguem, segundo a OMT, quatro elementos básicos:

- Demanda - conjunto de consumidores, ou potenciais consumidores, de bens e serviços turísticos;

- Oferta - conjunto de empresas, serviços e produtos inseridos no contexto da atividade turística;

- Espaço geográfico - lugar físico onde se encontram a oferta e a demanda, simultaneamente, e também em que se localiza a população residente, a qual, quando não é por si um atrativo, é um fator de coesão ou desagregação, dependendo do planejamento turístico do local;

- Operadores de mercado - são as agências de viagens, as companhias de transporte regular e as empresas privadas e os órgãos públicos que possuem o objetivo de facilitar a integração entre a oferta e a demanda. (OMT, 2001).

\subsection{Atuação e competências de formuladores de políticas públicas}

Os formuladores de políticas públicas possuem grande importância no desenvolvimento do Turismo, visto que eles atuam de forma gerencial e balizam as orientações centrais da atividade, com o intuito de promover o desenvolvimento sustentável, garantindo melhores condições sociais e econômicas para as populações locais dos destinos turísticos. Estes profissionais também objetivam alcançar um elevado grau de satisfação na experiência da viagem para os turistas. Sendo assim, de acordo com Beni (2001), a atividade não pode ser tratada com ações pontuais e isoladas, que beneficiam somente alguns atores, mas deve-se observar a importância da adoção e da elaboração de políticas públicas de maneira comprometida e diretamente relacionada à realidade da localidade, a fim de 
identificar as potencialidades, as deficiências, as condições favoráveis e quaisquer limitações de ordem técnico-administrativa.

Segundo Cooper et. al. (2001), turismo é uma oportunidade de negócios que pode promover ou comprometer o desenvolvimento de uma destinação. Os autores elencam a existência de onze argumentos clássicos que fundamentam o envolvimento do setor público no direcionamento do desenvolvimento turístico:

I. Captação de moeda estrangeira e sua importância na balança de pagamentos;

II. Geração de emprego e a necessidade de proporcionar ações de educação e treinamento, para qualificar a mão-de-obra;

III. Coordenação e desenvolvimento de ações de promoção dos destinos turísticos;

IV. Maximização dos benefícios para a comunidade anfitriã;

V. Distribuição dos benefícios e divisão dos custos de forma eqüitativa;

VI. Construção da imagem do país como destinação turística;

VII. Regulamentação do mercado para proteger consumidores e impedir concorrência desleal;

VIII. Fornecimento de bens públicos e infra-estrutura como parte do serviço turístico;

IX. Proteção do meio-ambiente e dos patrimônios material e imaterial;

X. Regulamentação dos aspectos do comportamento social, por meio de pesquisas de acompanhamento da população local e dos turistas;

XI. Monitoramento do nível da atividade turística, através de levantamentos estatíticos.

Corroborando com o autor e complementando as atribuições elencadas, Ignarra (2001), argumenta que cabe ao Estado, entre outras funcões, o planejamento do fomento da atividade turística; o controle da qualidade dos produtos e serviços ofertados; a promoção institucional das destinações; o financiamento e a captação dos investimentos da iniciativa privada para o setor; a captação de recursos humanos; o controle do uso e da conscientização do patrimônio turístico; a captação, o tratamento e a distribuição da informação da atividade; a implementação e a manutenção da infra-estrutura urbana básica; a prestação de serviços de segurança pública; o desenvolvimentos de campanhas de conscientização turística; o apoio ao desenvolvimento de atividades culturais locais (artesanato, folclore, gastronomia típica); a implantação e manutenção de infra-estrutura turística, voltada para a população de baixa- 
renda e; a implantação e a operação de sistemas estatísticos de acompanhamento mercadológico.

Portanto, o turismo, enquanto atividade econômica, possui enorme potencial de alavancar o desenvolvimento de uma região quando os formuladores de políticas públicas atuarem de forma global e holística.

No próximo capítulo, serão apresentados os métodos e as técnicas de pesquisa para identificar as competências necessárias aos profissionais formuladores das políticas públicas da SETUR, levando-se em consideração as características específicas da atividade turística. 


\section{METODOLOGIA}

O presente capítulo objetiva clarificar as escolhas e os procedimentos metodológicos adotados na pesquisa, os quais foram utilizados de forma coerente e adequada com o problema de estudo apresentado. A seguir, são apresentados o tipo de pesquisa, as características da organização pesquisada, a população e amostra e os instrumentos e procedimento para coleta de dados da pesquisa.

\subsection{Tipos de pesquisa}

A pesquisa deve ser vista sempre como uma expectativa de acumulação do saber organizado para o desenvolvimento de uma consciência crítica e isenta de vícios. É também o instrumento de ação para que os conhecimentos possam ser úteis à coletividade. Disso deduzse que o homem pesquisa para explicar fenômenos, para criar novos instrumentos, equipamentos e máquinas e para alcançar objetivos pré-determinados (SANTOS, 2005).

Este estudo terá uma abordagem metodológica essencialmente exploratória, descritiva e aplicada. A presente pesquisa, segundo tipologia sugerida por Vergara (2000), possui o caráter exploratório, visto que é realizada em uma organização onde a gestão por competências e a identificação das mesmas não são um fator analisado de forma sistemática. Também é descritiva porque apresenta características próprias da população pesquisada e busca estabelecer correlações entre as variáveis. Todavia, não possui o objetivo de explicar os fenômenos que descreve. Por fim, pode-se dizer que a pesquisa é aplicada devido à intenção de apresentar subsídios para identificar o grau de importância e o grau de domínio das competências existentes, bem como a lacuna entre estas e as necessárias ao alcance da estratégia organizacional.

Para Barros e Lehfeld (2000, p.64), “em pesquisas, seja qual for a sua tipologia, o levantamento e seleção de uma bibliografia concernente é um pré-requisito indispensável para a construção e demonstração das características de um objeto de estudo". A busca do conhecimento por meio da bibliografia pertinente permite o enriquecimento do embasamento teórico do pesquisador. Desta forma, quanto aos meios, a pesquisa é bibliográfica, documental e de campo. Tendo em vista que a fundamentação teórica foi pesquisada, de forma sistemática, e obtida através da análise de material publicado em livros, artigos científicos, revistas especializadas, legislações específicas, teses e sites na internet, a pesquisa é dita bibliográfica. Para o alcance dos objetivos propostos, a investigação documental foi outro 
meio de obtenção de informações, visto que foram analisados documentos relativos ao planejamento estratégico da organização e legislações aplicadas à mesma. Também foi realizada uma pesquisa de campo, por meio de entrevista individual e questionário, no intuito de delinear as competências existentes e as necessárias à consecução da estratégia organizacional. Os questionários foram elaborados de acordo com as competências necessárias identificadas na entrevista individual com a Assessora do Secretário e, concomitantemente, Gestora de Fomento.

\subsection{Contexto da pesquisa: objeto de análise}

A presente pesquisa tem como local de estudo a Secretaria de Turismo de Pernambuco. Criada no dia 3 de agosto de 2006, por meio do decreto n ${ }^{\circ} 29.508$, a Setur é um órgão da Administração Direta do Poder Executivo Estadual, que está estruturado, originalmente, da seguinte maneira: Chefia de Gabinete, Secretaria Executiva de Turismo (subdividida em Gerência Geral de Fomento e Gerência Geral de Articulação), Superintendência de Gestão, Coordenadoria de Planejamento, Ouvidoria, Assessoria, Secretaria de Gabinete, Serviços Auxiliares de Gabinete e.Comissão Permanente de Licitação. (PERNAMBUCO, 2006)

\subsection{População e Amostra}

De acordo com Richardson (1999), população é o conjunto de elementos que possuem determinadas características. Em termos estatísticos, população pode ser o conjunto de indivíduos que trabalham em um mesmo lugar. Cada unidade ou membro de uma população denomina-se elemento e, quando se toma certo número de elementos para averiguar algo sobre a população à qual pertencem, fala-se de amostra. Kotler e Armstrong (2003, p.104) definem amostra como "um segmento da população selecionado para representar a população como um todo".

$\mathrm{Na}$ realização da pesquisa, serão identificadas as competências relativas aos profissionais que participam, direta e indiretamente, na formulação de políticas públicas de turismo, que atuam nas seguintes áreas da Setur: Secretaria Executiva, Gerência Geral de Fomento, Gerência Geral de Articulação e Gerência de Empreendimentos Turísticos.

Para a escolha dos componentes da amostra foi utilizado o método não-probabilístico e por acesso, onde "o pesquisador pode, arbitrária ou conscientemente, decidir os elementos a 
serem incluídos na amostra" (MALHOTRA, 2001, p. 305). Em virtude da criação recente da Secretaria, algumas gerências ainda estão em fase de desenvolvimento e não possuem profissionais atuando em sua estrutura. Assim, buscou-se pesquisar a totalidade da população, que se configura em 7 respondentes, em razão do reduzido número de profissionais da Setur,

\subsection{Coleta de dados}

Para atingir os objetivos propostos e visando uma avaliação abrangente em profundidade dos tópicos, as técnicas utilizadas foram pesquisas bibliográficas e documental, realização de entrevista individual e aplicação de questionário fechado aos profissionais formuladores de políticas públicas da Setur.

Inicialmente realizou-se um levantamento bibliográfico, buscando-se determinar quais trabalhos já haviam sido realizados por outros pesquisadores que abordassem a mesma problemática deste estudo. Uma pesquisa nos registros documentais da organização também foi realizada, a fim de identificar sua missão, seus objetivos e seu planejamento estratégico.

Para Richardson (1999), em todas as ações que envolvem indivíduos, é relevante que as pessoas compreendam o que ocorre com os outros. Portanto, a entrevista é uma técnica importante que permite o desenvolvimento de uma estreita relação entre as pessoas. $\mathrm{O}$ autor explica que esta técnica é um modo de comunicação no qual determinada informação é transmitida de uma pessoa para a outra. Assim, para coletar os dados necessários à resolução do problema da pesquisa, as técnicas escolhidas foram a entrevista individual (Apêndice I) e o questionário (Apêndice II). De acordo com Carbone et. al (2006), o pesquisador deve selecionar a(s) pessoa(s) a ser(em) entrevistada(s) entre aquelas que possuem maior conhecimento da estratégia, dos negócios, dos produtos, dos processos e da cultura da organização. Assim, foi formulado um roteiro de perguntas, a fim de cotejar a percepção do entrevistado com os dados apurados na análise documental, visando identificar as competências necessárias aos profissionais da Setur. Nesta etapa, os desafios enfrentados por eles também foram ser elencados e analisados.

A entrevista individual foi realizada com a Assessora do Secretário de Turismo de Pernambuco e Gestora de Fomento, no dia 23 de abril de 2008, e teve a duração de 45 minutos. A entrevista semi-estruturada foi composta de cabeçalho com as informações sobre instituição de ensino; identificação do curso de pós-graduação; nome da pós-graduanda e; título do trabalho ao qual a pesquisa está vinculada. O roteiro da entrevista foi composto pelas definições de competência organizacional e competência individual e pelas seguintes 
questões: 1) "Fale sobre a Setur (missão, objetivos estratégicos, visão, características)"; 2) "Para alcançar a missão da organização, quais as principais atividades desenvolvidas pelos profissionais formuladores de políticas públicas, que atuam na Secretaria?”; 3) "Quais os desafios a serem enfrentados por estes profissionais?”; 4) "Que competências organizacionais você julga relevantes para a consecução dos objetivos da Setur? (a organização deve ser capaz de quê?)." e; 5) "Para que a Setur consiga concretizar sua estratégia, o que os profissionais devem conhecer, saber fazer e ter atitude para fazer?"

Esta entrevista teve como objetivo principal identificar as atribuições da Setur e, conseqüentemente, elencar as competências necessárias para executá-las.

A outra técnica utilizada para obter os dados necessários à resolução do problema da pesquisa foi o questionário, cuja elaboração deu-se através do aprimoramento das assertivas identificadas na entrevista individual, a fim de transformá-las em competências passíveis de serem mensuradas.

Segundo Carbone et. al. (2006), para verificar o grau de importância e o grau de domínio das competências identificadas por parte dos entrevistados, o questionário é a técnica de pesquisa mais comumente utilizada. Neste caso, explicam Brandão e Guimarães (2001), após elencar as competências necessárias por meio das outras técnicas utilizadas, deve-se ordená-las e editá-las, dentro das três dimensões do conceito de competências (conhecimentos, habilidades e atitudes). Nesta pesquisa, a escala de mensuração utilizada para identificar o grau de domínio e o grau de importância foi a escala Likert. De acordo com esta escala, todos os itens recebem rótulos específicos, onde: 0 - Sem importância; 1 - Pouco importante; 2 - Importante e; 3 - Muito importante, na escala sobre o grau de importância de determinada competência e: 0 - Não domino; 1 - Possuo pouco domínio; 2 - Possuo domínio quase completo e; 3 - Domino completamente, com relação ao grau de domínio sobre a competência especificada.

O questionário foi elaborado com as informações sobre a instituição de ensino; identificação do curso de pós-graduação; nome da pós-graduanda e; título da pesquisa. A introdução do questionário foi composta por uma breve explicação sobre os objetivos da pesquisa, bem como pela informação do caráter acadêmico da pesquisa e do tratamento sigiloso dos dados e das respostas coletados. A seguir, foram apresentadas as escalas utilizadas para identificar o grau de importância da competência para o desempenho de suas atribuições profissionais, bem como o grau de domínio das referidas competências.

As competências que compuseram o questionário foram identificadas de acordo como resultado das pesquisas documental e bibliográfica, realizadas durante a primeira fase do 
estudo e com base na análise do conteúdo da entrevista semi-estruturada. Assim, foi possível elencar 19 conhecimentos, 17 habilidades e 12 atitudes relativas às atividades dos formuladores de políticas públicas da Setur, conforme demonstrado nos Quadros 2, 3 e 4, apresentados no capítulo referente ao resultados e à análise dos dados.

O questionário (Apêndice II) foi encaminhado aos 7 profissionais formuladores de políticas públicas, via e-mail, no dia 28 de maio, e as respostas foram devolvidas entre os dias 28 de maio e 06 de junho. 


\section{RESULTADO E ANÁLISE DOS DADOS}

Neste capítulo, são apresentados e analisados os resultados obtidos através da aplicação do questionário fechado, junto aos formuladores de políticas públicas da Setur. Os resultados foram categorizados de acordo com as três dimensões do conceito de competência (conhecimentos, habilidades e atitudes) e de acordo com as escalas definidas no subitem $3.4-$ "Coleta de dados" - do capítulo anterior. O Quadro 2 apresenta os conhecimentos identificados por meio do referido questionário; o Quadro 3 expõe as competências relativas à dimensão habilidades e; o Quadro 4 apresenta as atitudes.

\section{Quadro 2 - Conhecimentos identificados}

\begin{tabular}{|c|}
\hline Valores, objetivos, missão, planejamento estratégico da Setur \\
\hline Atribuições da Setur \\
\hline Limites de atuação da Setur \\
\hline Limite de atuação individual (seu papel dentro da Setur) \\
\hline Legislação relativa à atividade turística, aplicável às atividades desenvolvidas \\
\hline $\begin{array}{l}\text { Preparo de projetos turísticos em conformidade com a legislação referente à } \\
\text { Administração Pública }\end{array}$ \\
\hline $\begin{array}{l}\text { Execução de os projetos turísticos em conformidade com a legislação referente à } \\
\text { Administração Pública }\end{array}$ \\
\hline Aspectos teóricos relativos à atividade turística \\
\hline Aspectos práticos relativos ao turismo \\
\hline Técnicas de elaboração de projetos turísticos \\
\hline Técnicas de divulgação das destinações turísticas \\
\hline Técnicas de promoção das destinações turísticas \\
\hline Tramitação dos procedimentos administrativos internos \\
\hline Comunicação em língua portuguesa, na forma oral, com clareza e objetividade \\
\hline Comunicação em língua portuguesa, na forma escrita, com clareza e objetividade \\
\hline Comunicação em língua inglesa, na forma oral, com fluência \\
\hline
\end{tabular}


Comunicação em língua inglesa, na forma escrita, com fluência

Comunicação em língua espanhola, na forma oral, com fluência

Comunicação em língua espanhola, na forma escrita, com fluência

Fonte: Instrumento elaborado pela autora (2008)

\section{Quadro 3 - Habilidades identificadas}

Reconhecer o turismo como atividade interdependente, visto que, para seu desenvolvimento, são necessárias ações conjuntas com outros segmentos da sociedade

Reconhecer a atividade turística como global e local, simultaneamente, tendo em vista seu caráter dinâmico e suas especificidades

Manter bons relacionamentos interpessoais dentro da Setur

Manter bons relacionamentos interpessoais no ambiente externo à Setur

Trabalhar em equipe

Trabalhar de forma harmônica e integrada com as diversas áreas da Setur

Avaliar as políticas públicas executadas por outras secretarias de turismo, pautando-se por uma visão integradora e global

Analisar as políticas públicas da própria Setur-PE, de modo abrangente, mas também de acordo com as especificidades de cada localidade.

Justificar as demandas dos projetos turísticos existentes na Setur com embasamento sócio-político-econômico

Examinar as situações vivenciadas na Setur com a visão política do contexto

Reconhecer oportunidades de negócios, favoráveis à Setur em eventos externos

Identificar oportunidades de desenvolvimento do turismo, por meio dos diferentes tipos da atividade (pedagógico, religioso, de eventos, de laser)

Identificar novas localidades para a exploração sustentável da atividade turística

Captar recursos financeiros para o desenvolvimento do turismo no Estado

Comparar os pontos de vista dos diferentes atores (comunidade, trade, turistas, órgãos de governo) da atividade turística

Aproveitar as ações exitosas, relacionadas ao planejamento turístico de outras secretarias

Adaptar as ações exitosas de outras secretarias à realidade de cada destinação turística

Fonte: Instrumento elaborado pela autora (2008) 


\section{Quadro 4 - Atitudes identificadas}

\begin{tabular}{|c|}
\hline $\begin{array}{c}\text { Incluir a comunidade local, no desenvolvimento dos projetos turísticos } \\
\text { Integrar os diferentes pontos de vista de diversos atores da atividade turística } \\
\text { (comunidade, trade, turistas, órgãos de governo) }\end{array}$ \\
\hline $\begin{array}{c}\text { Identificar iniciativas que maximizem os benefícios e condições favoráveis, advindas da } \\
\text { atividade turística para os diversos atores envolvidos no processo }\end{array}$ \\
\hline $\begin{array}{c}\text { Primar por escolher ações que Minimizem os impactos ambientais negativos, } \\
\text { causados pelo turismo }\end{array}$ \\
\hline Buscar ações que reduzam os impactos culturais negativos, \\
trazidos pela atividade turística \\
\hline Procurar mecanismos que atenuem os impactos negativos sócio-econômicos, \\
em decorrência do turismo
\end{tabular}

Fonte: Instrumento elaborado pela autora (2008)

A importância de determinada competência foi mensurada por meio do resultado das respostas dos participantes da pesquisa. Considerando-se a escala de quatro pontos, as competências que apresentam médias iguais ou superiores a dois indicam que o conhecimento, a habilidade ou a atitude avaliada possui importância para as atividades desenvolvidas pelos formuladores de políticas públicas da Setur e que os pesquisados consideram ter domínio sobre a referida competência.

De forma inversa, as competências com média inferior a dois foram consideradas com pouca ou nenhuma importância para os respondentes ou que estes declararam possuir pouco ou nenhum domínio sobre elas.

As competências que apresentaram as médias com maior grau de importância e menor grau de domínio evidenciaram a lacuna entre as competências existentes e aquelas necessárias à consecução dos objetivos da Setur, demonstrando a necessidade de realização de ações de desenvolvimento e capacitação na organização. 
Ressalta-se que, mesmo sem apresentarem domínio ou importância abaixo da média 2,00, considerou-se que existe uma lacuna de competências quando a média de domínio ficou abaixo da média de importância.

\subsection{Conhecimentos}

A seguir, serão apresentados os dados relativos à dimensão "Conhecimentos". Na Tabela 1, encontram-se os resultados, em números absolutos e em porcentuais, sobre o grau de importância de cada conhecimentos considerado pelos profissionais pesquisados. O grau de domínio assegurado por eles está expresso na Tabela 2. As médias e os desvios-padrão dos graus de importância e domínio encontram-se tabulados, respectivamente, nas Tabelas 3 e 4 .

Tabela 1 - Distribuição do grau de importância dos conhecimentos identificados.

\begin{tabular}{|c|c|c|c|c|c|c|c|c|}
\hline \multirow{3}{*}{ Ter conhecimento de } & \multicolumn{8}{|c|}{ Grau de importância } \\
\hline & \multicolumn{2}{|c|}{$\begin{array}{c}\text { Pouca } \\
\text { importância }\end{array}$} & \multicolumn{2}{|c|}{ Importante } & \multicolumn{2}{|c|}{$\begin{array}{c}\text { Muito } \\
\text { importante }\end{array}$} & \multicolumn{2}{|c|}{ TOTAL } \\
\hline & $\mathbf{n}$ & $\%$ & $\mathbf{n}$ & $\%$ & $\mathbf{n}$ & $\%$ & $\mathbf{n}$ & $\%$ \\
\hline Valores, objetivos, missão, planejamento estratégico da Setur & - & - & 2 & 28,6 & 5 & 71,4 & 7 & 100,0 \\
\hline Atribuições da Setur & - & - & 2 & 28,6 & 5 & 71,4 & 7 & 100,0 \\
\hline Limites de atuação da Setur & - & - & 2 & 28,6 & 5 & 71,4 & 7 & 100,0 \\
\hline Limite de atuação individual (seu papel dentro da Setur) & - & - & 2 & 28,6 & 5 & 71,4 & 7 & 100,0 \\
\hline $\begin{array}{l}\text { Legislação relativa à atividade turística, aplicável às atividades } \\
\text { desenvolvidas }\end{array}$ & - & - & - & - & 7 & 100,0 & 7 & 100,0 \\
\hline $\begin{array}{l}\text { Preparo de projetos turísticos em conformidade com a } \\
\text { legislação referente à Administração Pública }\end{array}$ & - & - & 3 & 42,9 & 4 & 57,1 & 7 & 100,0 \\
\hline $\begin{array}{l}\text { Execução de os projetos turísticos em conformidade com a } \\
\text { legislação referente à Administração Pública }\end{array}$ & - & - & 1 & 14,3 & 6 & 85,7 & 7 & 100,0 \\
\hline Aspectos teóricos relativos à atividade turística & - & - & 1 & 14,3 & 6 & 85,7 & 7 & 100,0 \\
\hline Aspectos práticos relativos ao turismo & - & - & 1 & 14,3 & 6 & 85,7 & 7 & 100,0 \\
\hline Técnicas de elaboração de projetos turísticos & - & - & - & - & 7 & 100,0 & 7 & 100,0 \\
\hline Técnicas de divulgação das destinações turísticas & - & - & - & - & 7 & 100,0 & 7 & 100,0 \\
\hline Técnicas de promoção das destinações turísticas & - & - & - & - & 7 & 100,0 & 7 & 100,0 \\
\hline Tramitação dos procedimentos administrativos internos & - & - & 3 & 42,9 & 4 & 57,1 & 7 & 100,0 \\
\hline $\begin{array}{l}\text { Comunicação em língua portuguesa, na forma oral, com clareza } \\
\text { e objetividade }\end{array}$ & - & - & 1 & 14,3 & 6 & 85,7 & 7 & 100,0 \\
\hline $\begin{array}{l}\text { Comunicação em língua portuguesa, na forma escrita, com } \\
\text { clareza e objetividade }\end{array}$ & - & - & 1 & 14,3 & 6 & 85,7 & 7 & 100,0 \\
\hline Comunicação em língua inglesa, na forma oral, com fluência & 1 & 14,3 & 3 & 42,9 & 3 & 42,9 & 7 & 100,0 \\
\hline Comunicação em língua inglesa, na forma escrita, com fluência & 1 & 14,3 & 3 & 42,9 & 3 & 42,9 & 7 & 100,0 \\
\hline Comunicação em língua espanhola, na forma oral, com fluência & 1 & 14,3 & 3 & 42,9 & 3 & 42,9 & 7 & 100,0 \\
\hline
\end{tabular}




\begin{tabular}{l|r|r|r|r}
\hline $\begin{array}{l}\text { Comunicação em língua espanhola, na forma escrita, com } \\
\text { fluência }\end{array}$ & $1 \quad 14,3$ & 3 & 42,9 & 3 \\
\hline
\end{tabular}

Tabela 2 - Distribuição do grau de domínio dos conhecimentos identificados.

\begin{tabular}{|c|c|c|c|c|c|c|c|c|}
\hline \multirow{3}{*}{ Ter conhecimento de } & \multicolumn{8}{|c|}{ Grau de domínio } \\
\hline & \multicolumn{2}{|c|}{$\begin{array}{l}\text { Pouco } \\
\text { domínio }\end{array}$} & \multicolumn{2}{|c|}{$\begin{array}{l}\text { Domínio quase } \\
\text { completo }\end{array}$} & \multicolumn{2}{|c|}{$\begin{array}{c}\text { Domínio } \\
\text { completo }\end{array}$} & \multicolumn{2}{|c|}{ TOTAL } \\
\hline & $\mathbf{n}$ & $\%$ & $\mathbf{n}$ & $\%$ & $\mathbf{n}$ & $\%$ & $\mathbf{n}$ & $\%$ \\
\hline Valores, objetivos, missão, planejamento estratégico da Setur & - & - & 3 & 42,9 & 4 & 57,1 & 7 & 100,0 \\
\hline Atribuições da Setur & 1 & 14,3 & 2 & 28,6 & 4 & 57,1 & 7 & 100,0 \\
\hline Limites de atuação da Setur & 1 & 14,3 & 2 & 28,6 & 4 & 57,1 & 7 & 100,0 \\
\hline Limite de atuação individual (seu papel dentro da Setur) & - & - & 1 & 14,3 & 6 & 85,7 & 7 & 100,0 \\
\hline $\begin{array}{l}\text { Legislação relativa à atividade turística, aplicável às atividades } \\
\text { desenvolvidas }\end{array}$ & - & - & 3 & 42,9 & 4 & 57,1 & 7 & 100,0 \\
\hline $\begin{array}{l}\text { Preparo de projetos turísticos em conformidade com a legislação } \\
\text { referente à Administração Pública }\end{array}$ & - & - & 3 & 42,9 & 4 & 57,1 & 7 & 100,0 \\
\hline $\begin{array}{l}\text { Execução de os projetos turísticos em conformidade com a } \\
\text { legislação referente à Administração Pública }\end{array}$ & - & - & 3 & 42,9 & 4 & 57,1 & 7 & 100,0 \\
\hline Aspectos teóricos relativos à atividade turística & - & - & 2 & 28,6 & 5 & 71,4 & 7 & 100,0 \\
\hline Aspectos práticos relativos ao turismo & - & - & 2 & 28,6 & 5 & 71,4 & 7 & 100,0 \\
\hline Técnicas de elaboração de projetos turísticos & 1 & 14,3 & 2 & 28,6 & 4 & 57,1 & 7 & 100,0 \\
\hline Técnicas de divulgação das destinações turísticas & 1 & 14,3 & 2 & 28,6 & 4 & 57,1 & 7 & 100,0 \\
\hline Técnicas de promoção das destinações turísticas & 1 & 14,3 & 2 & 28,6 & 4 & 57,1 & 7 & 100,0 \\
\hline Tramitação dos procedimentos administrativos internos & - & - & 2 & 28,6 & 5 & 71,4 & 7 & 100,0 \\
\hline $\begin{array}{l}\text { Comunicação em língua portuguesa, na forma oral, com clareza } \\
\text { e objetividade }\end{array}$ & - & - & 1 & 14,3 & 6 & 85,7 & 7 & 100,0 \\
\hline $\begin{array}{l}\text { Comunicação em língua portuguesa, na forma escrita, com } \\
\text { clareza e objetividade }\end{array}$ & - & - & 2 & 28,6 & 5 & 71,4 & 7 & 100,0 \\
\hline Comunicação em língua inglesa, na forma oral, com fluência & - & - & 2 & 28,6 & 5 & 71,4 & 7 & 100,0 \\
\hline Comunicação em língua inglesa, na forma escrita, com fluência & - & - & 2 & 28,6 & 5 & 71,4 & 7 & 100,0 \\
\hline Comunicação em língua espanhola, na forma oral, com fluência & 1 & 14,3 & 2 & 28,6 & 4 & 57,1 & 7 & 100,0 \\
\hline $\begin{array}{l}\text { Comunicação em língua espanhola, na forma escrita, com } \\
\text { fluência }\end{array}$ & 1 & 14,3 & 2 & 28,6 & 4 & 57,1 & 7 & 100,0 \\
\hline
\end{tabular}

Tabela 3 - Média e desvio-padrão do grau de importância dos conhecimentos identificados.

\begin{tabular}{l|c|c|c}
\hline \multicolumn{1}{|c|}{ Estatísticas } & \multicolumn{2}{c}{ Mesvio } & Mínimo \\
Ter conhecimento de & Média & 0,49 & 2 \\
\hline Valores, objetivos, missão, planejamento estratégico da Setur & 2,71 & 0,49 & 2 \\
\hline Atribuições da Setur & 2,71 & 0,49 & 2 \\
\hline Limites de atuação da Setur & 2,71 & 0,49 & 2 \\
\hline Limite de atuação individual (seu papel dentro da Setur) & 2,71 & 3 \\
\hline $\begin{array}{l}\text { Legislação relativa à atividade turística, aplicável às atividades } \\
\text { desenvolvidas }\end{array}$ & 3,00 & 0,00 & 3 \\
\hline
\end{tabular}




\begin{tabular}{|c|c|c|c|c|}
\hline $\begin{array}{l}\text { Preparo de projetos turísticos em conformidade com a legislação } \\
\text { referente à Administração Pública }\end{array}$ & 2,57 & 0,54 & 2 & 3 \\
\hline $\begin{array}{l}\text { Execução de os projetos turísticos em conformidade com a } \\
\text { legislação referente à Administração Pública }\end{array}$ & 2,86 & 0,38 & 2 & 3 \\
\hline Aspectos teóricos relativos à atividade turística & 2,86 & 0,38 & 2 & 3 \\
\hline Aspectos práticos relativos ao turismo & 2,86 & 0,38 & 2 & 3 \\
\hline Técnicas de elaboração de projetos turísticos & 3,00 & 0,00 & 3 & 3 \\
\hline Técnicas de divulgação das destinações turísticas & 3,00 & 0,00 & 3 & 3 \\
\hline Técnicas de promoção das destinações turísticas & 3,00 & 0,00 & 3 & 3 \\
\hline Tramitação dos procedimentos administrativos internos & 2,57 & 0,54 & 2 & 3 \\
\hline $\begin{array}{l}\text { Comunicação em língua portuguesa, na forma oral, com clareza } \\
\text { e objetividade }\end{array}$ & 2,86 & 0,38 & 2 & 3 \\
\hline $\begin{array}{l}\text { Comunicação em língua portuguesa, na forma escrita, com } \\
\text { clareza e objetividade }\end{array}$ & 2,86 & 0,38 & 2 & 3 \\
\hline Comunicação em língua inglesa, na forma oral, com fluência & 2,29 & 0,76 & 1 & 3 \\
\hline Comunicação em língua inglesa, na forma escrita, com fluência & 2,29 & 0,76 & 1 & 3 \\
\hline Comunicação em língua espanhola, na forma oral, com fluência & 2,29 & 0,76 & 1 & 3 \\
\hline $\begin{array}{l}\text { Comunicação em língua espanhola, na forma escrita, com } \\
\text { fluência }\end{array}$ & 2,29 & 0,76 & 1 & 3 \\
\hline
\end{tabular}

Tabela 4 - Média e desvio-padrão do grau de domínio dos conhecimentos identificados.

\begin{tabular}{|c|c|c|c|c|}
\hline \multirow[b]{2}{*}{ Ter conhecimento de } & \multicolumn{4}{|c|}{ Estatísticas } \\
\hline & Média & $\begin{array}{l}\text { Desvio } \\
\text { padrão }\end{array}$ & Mínimo & Máximo \\
\hline Valores, objetivos, missão, planejamento estratégico da Setur & 2,57 & 0,54 & 2 & 3 \\
\hline Atribuições da Setur & 2,43 & 0,79 & 1 & 3 \\
\hline Limites de atuação da Setur & 2,43 & 0,79 & 1 & 3 \\
\hline Limite de atuação individual (seu papel dentro da Setur) & 2,86 & 0,38 & 2 & 3 \\
\hline $\begin{array}{l}\text { Legislação relativa à atividade turística, aplicável às atividades } \\
\text { desenvolvidas }\end{array}$ & 2,57 & 0,54 & 2 & 3 \\
\hline $\begin{array}{l}\text { Preparo de projetos turísticos em conformidade com a legislação } \\
\text { referente à Administração Pública }\end{array}$ & 2,57 & 0,54 & 2 & 3 \\
\hline $\begin{array}{l}\text { Execução de os projetos turísticos em conformidade com a } \\
\text { legislação referente à Administração Pública }\end{array}$ & 2,57 & 0,54 & 2 & 3 \\
\hline Aspectos teóricos relativos à atividade turística & 2,71 & 0,49 & 2 & 3 \\
\hline Aspectos práticos relativos ao turismo & 2,71 & 0,49 & 2 & 3 \\
\hline Técnicas de elaboração de projetos turísticos & 2,43 & 0,79 & 1 & 3 \\
\hline Técnicas de divulgação das destinações turísticas & 2,43 & 0,79 & 1 & 3 \\
\hline Técnicas de promoção das destinações turísticas & 2,43 & 0,79 & 1 & 3 \\
\hline Tramitação dos procedimentos administrativos internos & 2,71 & 0,49 & 2 & 3 \\
\hline $\begin{array}{l}\text { Comunicação em língua portuguesa, na forma oral, com clareza } \\
\text { e objetividade }\end{array}$ & 2,86 & 0,38 & 2 & 3 \\
\hline $\begin{array}{l}\text { Comunicação em língua portuguesa, na forma escrita, com } \\
\text { clareza e objetividade }\end{array}$ & 2,71 & 0,49 & 2 & 3 \\
\hline
\end{tabular}




\begin{tabular}{l|c|c|c}
\hline Comunicação em língua inglesa, na forma oral, com fluência & 2,71 & 0,49 & 2 \\
\hline Comunicação em língua inglesa, na forma escrita, com fluência & 2,71 & 0,49 & 2 \\
\hline Comunicação em língua espanhola, na forma oral, com fluência & 2,43 & 0,79 & 1 \\
\hline $\begin{array}{l}\text { Comunicação em língua espanhola, na forma escrita, com } \\
\text { fluência }\end{array}$ & 2,43 & 0,79 & 3 \\
\hline
\end{tabular}

O conhecimento de "Valores, objetivos, missão, planejamento estratégico da Setur" foi avaliado por cinco entrevistados como uma competência muito importante para o desenvolvimento das atividades dos formuladores de políticas públicas da organização pesquisada; duas pessoas responderam que o consideram importante. Nenhum dos respondentes considerou pouco importante ou sem importância este conhecimento.

Ressalta-se, portanto, que todos participantes da pesquisa (soma de muito importante e importante) reconhecem a importância desta competência.

Com relação ao grau de domínio, quatro formuladores responderam que dominam completamente o conhecimento sobre "Valores, objetivos, missão, planejamento estratégico da Setur"; três deles afirmaram que possuem domínio quase completo e; não houve respostas que indicassem pouco ou nenhum domínio sobre este conhecimento.

Da relação entre os graus de importância e de domínio, conclui-se que os respondentes possuem conhecimento acerca dos "Valores, objetivos, missão, planejamento estratégico da Setur", sendo este conhecimento um dos que ocupa o terceiro lugar, tanto na escala de importância (média 2,71), quanto na de domínio (média 2,57). Esta constatação indica que não há necessidade de ações de capacitação com este objetivo.

Outra assertiva é sobre o conhecimento a respeito das "Atribuições da Setur". Cinco formuladores pesquisados afirmaram que este conhecimento é muito importante e outros dois atribuíram o grau de importante. Novamente, nenhum dos pesquisados imputou pouca ou nenhuma importância à referida competência.

Quanto ao grau de domínio, quatro entrevistados afirmaram que possuem domínio completo sobre o referido conhecimento. Já duas pessoas indicaram que possuem domínio quase completo e uma afirmou que possui pouco domínio. Nenhum formulador pesquisado afirmou não dominar o conhecimento sobre as "Atribuições da Setur".

Este conhecimento ficou com média de 2,71 na escala de importância e 2,43 na de domínio. O desvio-padrão de 0,79 , constatado no grau de domínio, indica divergência entre os formuladores de políticas públicas. Este item ficou em terceiro na ordem de importância e em quarto lugar com relação ao domínio. 
Da análise dos graus de importância e de domínio, pode-se afirmar que eles reconhecem a importância de tal conhecimento e possuem relativo domínio, não necessitando de ações prioritárias de capacitação e de desenvolvimento.

O conhecimento "Limites de atuação da Setur" também é considerado por cinco pesquisados como muito importante, enquanto que dois consideram-no importante para realização das atividades desenvolvidas pela Setur. Verifica-se que, mais uma vez, nenhum dos entrevistados atribuiu pouca ou nenhuma importância a este conhecimento.

Quanto ao grau de domínio, as respostas variaram entre o domínio completo e o pouco domínio, onde quatro entrevistados afirmaram que possuem domínio completo sobre o conhecimento dos "Limites de atuação da Setur"; dois indicaram que possuem domínio quase completo; e um afirmou que possui pouco domínio. Nenhum formulador pesquisado afirmou não dominar o referido conhecimento.

Observa-se que este conhecimento recebeu a mesma avaliação do item anterior (“Atribuições da Setur”) com relação aos graus de importância e de domínio, o que indica não haver necessidade de priorizar ações que desenvolvam esta competência.

Com relação ao conhecimento sobre o "Limite de atuação individual (seu papel dentro da Setur)", cinco entrevistados responderam que consideraram muito importante e dois deles afirmaram ser importante. Acompanhando as respostas anteriores, nenhum dos respondentes atribuiu pouca ou nenhuma importância a este conhecimento.

$\mathrm{Na}$ escala de domínio da referida competência, seis pessoas afirmaram que possuem completo domínio sobre este conhecimento e uma respondeu que possui domínio quase completo. Não houve relato de pouco ou nenhum domínio.

Percebe-se que os formuladores de políticas públicas possuem elevado conhecimento sobre seu "Limite de atuação individual (seu papel dentro da Setur)", apresentando este conhecimento a média 2,71 de importância (terceiro no número de ordem) e 2,86 na média de domínio, sendo um dos primeiros no ranking.

\section{"Legislação relativa à atividade turística, aplicável às atividades desenvolvidas"} foi avaliada pelos sete respondentes como um conhecimento muito importante. No entanto, com relação ao domínio sobre esta competência, quatro asseguraram que possuem o domínio completo e três afirmaram que possuem domínio quase completo.

Apesar de todos os respondentes possuírem um elevado grau de domínio, esta competência pode ser melhor desenvolvida dentro da organização, visto que foi uma das primeiras no ranking de importância, com média 3,00, e uma das terceiras na escala de domínio (média 2,57). 
$\mathrm{Na}$ visão dos formuladores de políticas públicas da Setur, quatro deles avaliaram o "Preparo de projetos turísticos em conformidade com a legislação referente à Administração Pública" um conhecimento muito importante. Já os outros três atribuíram o grau de importante. Nenhum respondente ponderou que este conhecimento possui pouca ou nenhuma importância.

Quanto ao grau de domínio, as respostas também ficaram restritas ao domínio completo (quatro respostas) e domínio quase completo (três atribuições).

Neste caso, a análise indica que os formuladores atribuíram nível médio de importância, com relação às demais competências, tendo em vista que este conhecimento ficou em quarto lugar, no quesito importância, e em terceiro, no domínio, com médias 2,57, não precisando de ações prioritárias de desenvolvimento desta competência.

O conhecimento "Execução de projetos turísticos em conformidade com a legislação referente à Administração Pública" recebeu de seis entrevistados o grau de muito importante e de apenas um o grau de importante.

No que se refere ao grau de domínio, quatro pesquisados afirmaram ter domínio completo e três declararam possuir domínio quase total sobre esta competência.

A análise indica que este item foi ordenado como segundo em importância (média 2,86) e como terceiro mais dominado (média 2,57), não havendo necessidade eminente de ações de capacitação para este conhecimento.

Com relação à importância dos "Aspectos teóricos relativos à atividade turística" e dos “Aspectos práticos relativos ao turismo", as respostas foram idênticas, onde a maioria dos formuladores (seis) atribuiu muita importância a estes conhecimentos, enquanto um achou que estes conhecimentos são importantes para o desempenho das atividades realizadas na Setur. Novamente, nenhum dos entrevistados atribuiu pouca ou nenhuma importância.

Corroborando com o resultado acima, o grau de domínio dos entrevistados também foi igual para os dois conhecimentos. Cinco pesquisados asseguraram que possuem domínio total sobre estes conhecimentos e dois afirmaram que possuem domínio quase completo sobre eles. Mais uma vez, nenhum dos entrevistados afirmou ter pouco ou nenhum domínio sobre os referidos conhecimentos.

Estes conhecimentos não prescindem de ações de desenvolvimento, tendo em vista que foram considerados como muito importantes, classificando-se em segundo no número de ordem no que se refere às médias de importância $(2,86)$ e de domínio $(2,71)$.

As respostam indicam que os três próximos conhecimentos também apresentaram resultados idênticos uns aos outros. Todos os pesquisados responderam que consideram muito 
importante o conhecimento sobre as "Técnicas de elaboração de projetos turísticos", sobre "Técnicas de divulgação das destinações turísticas" e "Técnicas de promoção das destinações turísticas" para o efetivo desenvolvimento das atividades na organização.

Com relação ao domínio que os formuladores possuem sobre estas técnicas, as respostam variaram entre domínio completo a pouco domínio, sendo que quatro afirmaram que possuem domínio completo; dois declararam que possuem domínio quase completo e um considerou que possui pouco domínio sobre o conhecimento dessas competências. Nenhum entrevistado afirmou não dominar este conhecimento.

Estes conhecimentos foram os que mais apresentaram discrepância entre os graus de importância e de domínio. De acordo com o resultado da análise dos dados, verificou-se que a média de importância é a mais elevada. As "Técnicas de elaboração de projetos turísticos", sobre "Técnicas de divulgação das destinações turísticas" e "Técnicas de promoção das destinações turísticas" foram consideradas o conhecimento mais importante (média 3,00) e o quarto e último menos dominado $(2,43)$.

O desvio-padrão de 0,79 em relação ao domínio indica que houve divergência de opinião entre os formuladores de políticas públicas da Setur.

Apesar de possuírem domínio sobre esta competência, o resultado indica que existe uma lacuna entre os conhecimentos existentes e entre aqueles necessários ao desempenho das atribuições dos referidos profissionais.

A “Tramitação dos procedimentos administrativos internos" foi considerada por quatro entrevistados como muito importante e, para os outros três, este conhecimento é considerado como importante. Não houve atribuição de pouca importância ou nenhuma importância para este conhecimento.

$\mathrm{Na}$ escala de domínio, cinco entrevistados afirmaram que possuem domínio total em relação à "Tramitação dos procedimentos administrativos internos", enquanto que dois deles asseguraram que possuem domínio quase total sobre este conhecimento. Pouca importância e sem importância não foram mencionadas.

Para este conhecimento, em relação aos demais, não foi atribuída muita importância (quarto em importância e média 2,57). Entretanto, os formuladores afirmaram que possuem elevado domínio (média 2,71), indicando que esta competência não necessita ser priorizada dentro das ações que visem a diminuição nas lacunas de competências.

No que se refere à importância sobre "Comunicação em língua portuguesa, na forma oral, com clareza e objetividade", do total de entrevistados, seis avaliaram este conhecimento muito importante e um declarou-o importante. 
Igual porcentagem obteve o grau de domínio, onde a maioria dos formuladores de políticas públicas da Setur (seis) afirmou que possui domínio completo e um declarou possuir domínio quase completo.

Este conhecimento obteve a mesma média $(2,86)$, tanto em importância quanto em domínio. Porém, foi considerado o segundo mais importante no número de ordem em importância e o primeiro, em domínio, indicando que não há lacuna de competências para o efetivo desenvolvimento das atividades da organização.

Os relatos comprovam que a totalidade dos entrevistados considerou a "Comunicação em língua portuguesa, na forma escrita, com clareza e objetividade" muito importante (seis respondentes) ou importante (um formulador).

Já em relação ao grau de domínio, este percentual de resposta variou entre cinco entrevistados, que declaram possuir domínio completo, e dois que afirmaram possuir domínio quase completo. Nenhum dos respondentes afirmou possuir pouco ou nenhum domínio sobre esta competência.

De acordo com a análise, este conhecimento foi considerado como o segundo mais importante (média 2,86) e como o segundo mais dominado (média 2,71), não necessitando de ações de desenvolvimento e capacitação por parte da organização.

As respostam indicam que os conhecimentos de "Comunicação em língua inglesa, na forma oral, com fluência" e "Comunicação em língua inglesa, na forma escrita, com fluência" obtiveram a mesma porcentagem tanto em relação ao grau de importância, quanto em relação ao grau de domínio. Para os referidos conhecimentos, três entrevistados atribuíram muita importância; outros três afirmaram ter importância e apenas um entrevistado declarou que é pouco importante. Nenhum respondente afirmou ser este conhecimento sem importância.

O resultado com relação ao grau de domínio estabeleceu-se com cinco respondentes afirmando possuir domínio completo sobre estes conhecimentos, enquanto dois declararam possuir domínio quase completo. Pouco domínio e nenhum domínio não foram citados.

Os referidos conhecimentos foram considerados como menos importantes (média 2,29), ocupando o quinto lugar no ranking e apresentaram elevado grau de domínio (média 2,71), onde se conclui não haver lacuna de competências.

O desvio-padrão de 0,76 , em relação à importância deste conhecimento, indica que houve divergência de opinião entre os formuladores de políticas públicas da Setur.

Por fim, entre os conhecimentos analisados, três formuladores consideraram a tanto a “Comunicação em língua espanhola, na forma oral, com fluência”, quanto a 
"Comunicação em língua espanhola, na forma escrita, com fluência” como muito importante; outros três consideraram-nas importante e um atribuiu pouca importância a estas competências. Nenhum respondente afirmou não ter importância.

Do total de pesquisados, quatro declararam dominar completamente as referidas competências, enquanto dois asseguraram que possuem domínio quase completo e um possui pouco domínio sobre estes conhecimentos. Não houve quem afirmasse não dominá-la.

Estes conhecimentos foram considerados os últimos em suas respectivas escalas, situando-se em quinto em importância (média 2,29) e em quarto com relação ao domínio (média 2,43) e, portanto, não são indicados para ações de capacitação.

Os desvios-padrão 0,76 e 0,79 , respectivamente, de importância e de domínio indicam que houve discordância entre os pesquisados.

\subsection{Habilidades}

Os dados relativos à dimensão "Habilidades" estão tabulados nas Tabelas 5, 6, 7 e 8. $\mathrm{Na}$ tabela 5, encontram-se os resultados, apresentados em números absolutos e em porcentuais, sobre o grau de importância de cada habilidade analisada pelos profissionais pesquisados. O grau de domínio declarado por eles está expresso na Tabela 6. Por sua vez, as médias e os desvios-padrão dos graus de importância e de domínio encontram-se, respectivamente, nas Tabelas 7 e 8 .

Tabela 5 - Distribuição do grau de importância das habilidades identificadas.

\begin{tabular}{|c|c|c|c|c|c|c|c|c|}
\hline \multirow{3}{*}{ Ter habilidade para } & \multicolumn{8}{|c|}{ Grau de importância } \\
\hline & \multicolumn{2}{|c|}{$\begin{array}{c}\text { Pouca } \\
\text { importância }\end{array}$} & \multicolumn{2}{|c|}{ Importante } & \multicolumn{2}{|c|}{$\begin{array}{c}\text { Muito } \\
\text { importante }\end{array}$} & \multicolumn{2}{|c|}{ TOTAL } \\
\hline & $\mathbf{n}$ & $\%$ & $\mathbf{n}$ & $\%$ & $\mathbf{n}$ & $\%$ & $\mathbf{n}$ & $\%$ \\
\hline $\begin{array}{l}\text { Reconhecer o turismo como atividade interdependente, visto } \\
\text { que, para seu desenvolvimento, são necessárias ações conjuntas } \\
\text { com outros segmentos da sociedade }\end{array}$ & - & - & 2 & 28,6 & 5 & 71,4 & 7 & 100,0 \\
\hline $\begin{array}{l}\text { Reconhecer a atividade turística como global e local, } \\
\text { simultaneamente, tendo em vista seu caráter dinâmico e suas } \\
\text { especificidades }\end{array}$ & - & - & 2 & 28,6 & 5 & 71,4 & 7 & 100,0 \\
\hline Manter bons relacionamentos interpessoais dentro da Setur & - & - & 1 & 14,3 & 6 & 85,7 & 7 & 100,0 \\
\hline $\begin{array}{l}\text { Manter bons relacionamentos interpessoais no ambiente externo } \\
\text { à Setur }\end{array}$ & - & - & 1 & 14,3 & 6 & 85,7 & 7 & 100,0 \\
\hline Trabalhar em equipe & - & - & 1 & 14,3 & 6 & 85,7 & 7 & 100,0 \\
\hline $\begin{array}{l}\text { Trabalhar de forma harmônica e integrada com as diversas áreas } \\
\text { da Setur }\end{array}$ & - & - & - & - & 7 & 100,0 & 7 & 100,0 \\
\hline
\end{tabular}




\begin{tabular}{|c|c|c|c|c|c|c|c|c|}
\hline $\begin{array}{l}\text { Avaliar as políticas públicas executadas por outras secretarias de } \\
\text { turismo, pautando-se por uma visão integradora e global }\end{array}$ & - & - & 2 & 28,6 & 5 & 71,4 & 7 & 100,0 \\
\hline $\begin{array}{l}\text { Analisar as políticas públicas da própria Setur-PE, de modo } \\
\text { abrangente, mas também de acordo com as especificidades de } \\
\text { cada localidade. }\end{array}$ & - & - & - & - & 7 & 100,0 & 7 & 100,0 \\
\hline $\begin{array}{l}\text { Justificar as demandas dos projetos turísticos existentes na Setur } \\
\text { com embasamento sócio-político-econômico }\end{array}$ & - & - & 1 & 14,3 & 6 & 85,7 & 7 & 100,0 \\
\hline $\begin{array}{l}\text { Examinar as situações vivenciadas na Setur com a visão política } \\
\text { do contexto }\end{array}$ & - & - & 3 & 42,9 & 4 & 57,1 & 7 & 100,0 \\
\hline $\begin{array}{l}\text { Reconhecer oportunidades de negócios, favoráveis à Setur em } \\
\text { eventos externos }\end{array}$ & - & - & 3 & 42,9 & 4 & 57,1 & 7 & 100,0 \\
\hline $\begin{array}{l}\text { Identificar oportunidades de desenvolvimento do turismo, por } \\
\text { meio dos diferentes tipos da atividade (pedagógico, religioso, de } \\
\text { eventos, de laser) }\end{array}$ & - & - & 3 & 42,9 & 4 & 57,1 & 7 & 100,0 \\
\hline $\begin{array}{l}\text { Identificar novas localidades para a exploração sustentável da } \\
\text { atividade turística }\end{array}$ & - & - & - & - & 7 & 100,0 & 7 & 100,0 \\
\hline $\begin{array}{l}\text { Captar recursos financeiros para o desenvolvimento do turismo } \\
\text { no Estado }\end{array}$ & - & - & - & - & 7 & 100,0 & 7 & 100,0 \\
\hline $\begin{array}{l}\text { Comparar os pontos de vista dos diferentes atores (comunidade, } \\
\text { trade, turistas, órgãos de governo) da atividade turística }\end{array}$ & - & - & 1 & 14,3 & 6 & 85,7 & 7 & 100,0 \\
\hline $\begin{array}{l}\text { Aproveitar as ações exitosas, relacionadas ao planejamento } \\
\text { turístico de outras secretarias }\end{array}$ & - & - & 1 & 14,3 & 6 & 85,7 & 7 & 100,0 \\
\hline $\begin{array}{l}\text { Adaptar as ações exitosas de outras secretarias à realidade de } \\
\text { cada destinação turística }\end{array}$ & - & - & 1 & 14,3 & 6 & 85,7 & 7 & 100,0 \\
\hline
\end{tabular}

Tabela 6 - Distribuição do grau de domínio das habilidades identificadas.

\begin{tabular}{|c|c|c|c|c|c|c|c|c|}
\hline \multirow{3}{*}{ Ter habilidade para } & \multicolumn{6}{|c|}{ Grau de domínio } & & \\
\hline & \multicolumn{2}{|c|}{$\begin{array}{c}\text { Pouco } \\
\text { domínio }\end{array}$} & \multicolumn{2}{|c|}{$\begin{array}{l}\text { Domínio } \\
\text { quase } \\
\text { completo }\end{array}$} & \multicolumn{2}{|c|}{$\begin{array}{l}\text { Domínio } \\
\text { completo }\end{array}$} & \multicolumn{2}{|c|}{ TOTAL } \\
\hline & $\mathbf{n}$ & $\%$ & $\mathrm{n}$ & $\%$ & $\mathrm{n}$ & $\%$ & $\mathrm{n}$ & $\%$ \\
\hline $\begin{array}{l}\text { Reconhecer o turismo como atividade interdependente, visto } \\
\text { que, para seu desenvolvimento, são necessárias ações conjuntas } \\
\text { com outros segmentos da sociedade }\end{array}$ & - & - & 3 & 42,9 & 4 & 57,1 & 7 & 100,0 \\
\hline $\begin{array}{l}\text { Reconhecer a atividade turística como global e local, } \\
\text { simultaneamente, tendo em vista seu caráter dinâmico e suas } \\
\text { especificidades }\end{array}$ & - & - & 3 & 42,9 & 4 & 57,1 & 7 & 100,0 \\
\hline Manter bons relacionamentos interpessoais dentro da Setur & - & - & 2 & 28,6 & 5 & 71,4 & 7 & 100,0 \\
\hline $\begin{array}{l}\text { Manter bons relacionamentos interpessoais no ambiente externo } \\
\text { à Setur }\end{array}$ & - & - & 2 & 28,6 & 5 & 71,4 & 7 & 100,0 \\
\hline Trabalhar em equipe & - & - & 2 & 28,6 & 5 & 71,4 & 7 & 100,0 \\
\hline $\begin{array}{l}\text { Trabalhar de forma harmônica e integrada com as diversas áreas } \\
\text { da Setur }\end{array}$ & - & - & 2 & 28,6 & 5 & 71,4 & 7 & 100,0 \\
\hline $\begin{array}{l}\text { Avaliar as políticas públicas executadas por outras secretarias de } \\
\text { turismo, pautando-se por uma visão integradora e global }\end{array}$ & - & - & 3 & 42,9 & 4 & 57,1 & 7 & 100,0 \\
\hline
\end{tabular}




\begin{tabular}{|c|c|c|c|c|c|c|c|c|}
\hline $\begin{array}{l}\text { Analisar as políticas públicas da própria Setur-PE, de modo } \\
\text { abrangente, mas também de acordo com as especificidades de } \\
\text { cada localidade. }\end{array}$ & - & - & 4 & 57,1 & 3 & 42,9 & 7 & 100,0 \\
\hline $\begin{array}{l}\text { Justificar as demandas dos projetos turísticos existentes na Setur } \\
\text { com embasamento sócio-político-econômico }\end{array}$ & - & - & 4 & 57,1 & 3 & 42,9 & 7 & 100,0 \\
\hline $\begin{array}{l}\text { Examinar as situações vivenciadas na Setur com a visão política } \\
\text { do contexto }\end{array}$ & 1 & 14,3 & 4 & 57,1 & 2 & 28,6 & 7 & 100,0 \\
\hline $\begin{array}{l}\text { Reconhecer oportunidades de negócios, favoráveis à Setur em } \\
\text { eventos externos }\end{array}$ & 1 & 14,3 & 4 & 57,1 & 2 & 28,6 & 7 & 100,0 \\
\hline $\begin{array}{l}\text { Identificar oportunidades de desenvolvimento do turismo, por } \\
\text { meio dos diferentes tipos da atividade (pedagógico, religioso, de } \\
\text { eventos, de laser) }\end{array}$ & 1 & 14,3 & 4 & 57,1 & 2 & 28,6 & 7 & 100,0 \\
\hline $\begin{array}{l}\text { Identificar novas localidades para a exploração sustentável da } \\
\text { atividade turística }\end{array}$ & 1 & 14,3 & 2 & 28,6 & 4 & 57,1 & 7 & 100,0 \\
\hline $\begin{array}{l}\text { Captar recursos financeiros para o desenvolvimento do turismo } \\
\text { no Estado }\end{array}$ & 2 & 28,6 & 2 & 28,6 & 3 & 42,9 & 7 & 100,0 \\
\hline $\begin{array}{l}\text { Comparar os pontos de vista dos diferentes atores (comunidade, } \\
\text { trade, turistas, órgãos de governo) da atividade turística }\end{array}$ & 2 & 28,6 & 3 & 42,9 & 2 & 28,6 & 7 & 100,0 \\
\hline $\begin{array}{l}\text { Aproveitar as ações exitosas, relacionadas ao planejamento } \\
\text { turístico de outras secretarias }\end{array}$ & 2 & 28,6 & 3 & 42,9 & 2 & 28,6 & 7 & 100,0 \\
\hline $\begin{array}{l}\text { Adaptar as ações exitosas de outras secretarias à realidade de } \\
\text { cada destinação turística }\end{array}$ & 2 & 28,6 & 3 & 42,9 & 2 & 28,6 & 7 & 100,0 \\
\hline
\end{tabular}

Tabela 7 - Média e desvio-padrão do grau de importância das habilidades identificadas.

\begin{tabular}{|c|c|c|c|c|}
\hline \multirow[b]{2}{*}{ Ter habilidade para } & \multicolumn{4}{|c|}{ Estatísticas } \\
\hline & Média & $\begin{array}{l}\text { Desvio } \\
\text { padrão }\end{array}$ & Mínimo & Máximo \\
\hline $\begin{array}{l}\text { Reconhecer o turismo como atividade interdependente, visto } \\
\text { que, para seu desenvolvimento, são necessárias ações conjuntas } \\
\text { com outros segmentos da sociedade }\end{array}$ & 2,71 & 0,49 & 2 & 3 \\
\hline $\begin{array}{l}\text { Reconhecer a atividade turística como global e local, } \\
\text { simultaneamente, tendo em vista seu caráter dinâmico e suas } \\
\text { especificidades }\end{array}$ & 2,71 & 0,49 & 2 & 3 \\
\hline Manter bons relacionamentos interpessoais dentro da Setur & 2,86 & 0,38 & 2 & 3 \\
\hline $\begin{array}{l}\text { Manter bons relacionamentos interpessoais no ambiente externo } \\
\text { à Setur }\end{array}$ & 2,86 & 0,38 & 2 & 3 \\
\hline Trabalhar em equipe & 2,86 & 0,38 & 2 & 3 \\
\hline $\begin{array}{l}\text { Trabalhar de forma harmônica e integrada com as diversas áreas } \\
\text { da Setur }\end{array}$ & 3,00 & 0,00 & 3 & 3 \\
\hline $\begin{array}{l}\text { Avaliar as políticas públicas executadas por outras secretarias de } \\
\text { turismo, pautando-se por uma visão integradora e global }\end{array}$ & 2,71 & 0,49 & 2 & 3 \\
\hline $\begin{array}{l}\text { Analisar as políticas públicas da própria Setur-PE, de modo } \\
\text { abrangente, mas também de acordo com as especificidades de } \\
\text { cada localidade. }\end{array}$ & 3,00 & 0,00 & 3 & 3 \\
\hline
\end{tabular}




\begin{tabular}{|c|c|c|c|c|}
\hline $\begin{array}{l}\text { Justificar as demandas dos projetos turísticos existentes na Setur } \\
\text { com embasamento sócio-político-econômico }\end{array}$ & 2,86 & 0,38 & 2 & 3 \\
\hline $\begin{array}{l}\text { Examinar as situações vivenciadas na Setur com a visão política } \\
\text { do contexto }\end{array}$ & 2,57 & 0,54 & 2 & 3 \\
\hline $\begin{array}{l}\text { Reconhecer oportunidades de negócios, favoráveis à Setur em } \\
\text { eventos externos }\end{array}$ & 2,57 & 0,54 & 2 & 3 \\
\hline $\begin{array}{l}\text { Identificar oportunidades de desenvolvimento do turismo, por } \\
\text { meio dos diferentes tipos da atividade (pedagógico, religioso, de } \\
\text { eventos, de laser) }\end{array}$ & 2,57 & 0,54 & 2 & 3 \\
\hline $\begin{array}{l}\text { Identificar novas localidades para a exploração sustentável da } \\
\text { atividade turística }\end{array}$ & 3,00 & 0,00 & 3 & 3 \\
\hline $\begin{array}{l}\text { Captar recursos financeiros para o desenvolvimento do turismo } \\
\text { no Estado }\end{array}$ & 3,00 & 0,00 & 3 & 3 \\
\hline $\begin{array}{l}\text { Comparar os pontos de vista dos diferentes atores (comunidade, } \\
\text { trade, turistas, órgãos de governo) da atividade turística }\end{array}$ & 2,86 & 0,38 & 2 & 3 \\
\hline $\begin{array}{l}\text { Aproveitar as ações exitosas, relacionadas ao planejamento } \\
\text { turístico de outras secretarias }\end{array}$ & 2,86 & 0,38 & 2 & 3 \\
\hline $\begin{array}{l}\text { Adaptar as ações exitosas de outras secretarias à realidade de } \\
\text { cada destinação turística }\end{array}$ & 2,86 & 0,38 & 2 & 3 \\
\hline
\end{tabular}

Tabela 8 - Média e desvio-padrão do grau de domínio das habilidades identificadas.

\begin{tabular}{|c|c|c|c|c|}
\hline \multirow[b]{2}{*}{ Ter habilidade para } & \multicolumn{4}{|c|}{ Estatísticas } \\
\hline & Média & $\begin{array}{l}\text { Desvio } \\
\text { padrão }\end{array}$ & Mínimo & Máximo \\
\hline $\begin{array}{l}\text { Reconhecer o turismo como atividade interdependente, visto } \\
\text { que, para seu desenvolvimento, são necessárias ações conjuntas } \\
\text { com outros segmentos da sociedade }\end{array}$ & 2,57 & 0,54 & 2 & 3 \\
\hline $\begin{array}{l}\text { Reconhecer a atividade turística como global e local, } \\
\text { simultaneamente, tendo em vista seu caráter dinâmico e suas } \\
\text { especificidades }\end{array}$ & 2,57 & 0,54 & 2 & 3 \\
\hline Manter bons relacionamentos interpessoais dentro da Setur & 2,71 & 0,49 & 2 & 3 \\
\hline $\begin{array}{l}\text { Manter bons relacionamentos interpessoais no ambiente externo } \\
\text { à Setur }\end{array}$ & 2,71 & 0,49 & 2 & 3 \\
\hline Trabalhar em equipe & 2,71 & 0,49 & 2 & 3 \\
\hline $\begin{array}{l}\text { Trabalhar de forma harmônica e integrada com as diversas áreas } \\
\text { da Setur }\end{array}$ & 2,71 & 0,49 & 2 & 3 \\
\hline $\begin{array}{l}\text { Avaliar as políticas públicas executadas por outras secretarias de } \\
\text { turismo, pautando-se por uma visão integradora e global }\end{array}$ & 2,57 & 0,54 & 2 & 3 \\
\hline $\begin{array}{l}\text { Analisar as políticas públicas da própria Setur-PE, de modo } \\
\text { abrangente, mas também de acordo com as especificidades de } \\
\text { cada localidade. }\end{array}$ & 2,43 & 0,54 & 2 & 3 \\
\hline $\begin{array}{l}\text { Justificar as demandas dos projetos turísticos existentes na Setur } \\
\text { com embasamento sócio-político-econômico }\end{array}$ & 2,43 & 0,54 & 2 & 3 \\
\hline
\end{tabular}




\begin{tabular}{|c|c|c|c|c|}
\hline $\begin{array}{l}\text { Examinar as situações vivenciadas na Setur com a visão política } \\
\text { do contexto }\end{array}$ & 2,14 & 0,69 & 1 & 3 \\
\hline $\begin{array}{l}\text { Reconhecer oportunidades de negócios, favoráveis à Setur em } \\
\text { eventos externos }\end{array}$ & 2,14 & 0,69 & 1 & 3 \\
\hline $\begin{array}{l}\text { Identificar oportunidades de desenvolvimento do turismo, por } \\
\text { meio dos diferentes tipos da atividade (pedagógico, religioso, de } \\
\text { eventos, de laser) }\end{array}$ & 2,14 & 0,69 & 1 & 3 \\
\hline $\begin{array}{l}\text { Identificar novas localidades para a exploração sustentável da } \\
\text { atividade turística }\end{array}$ & 2,43 & 0,79 & 1 & 3 \\
\hline $\begin{array}{l}\text { Captar recursos financeiros para o desenvolvimento do turismo } \\
\text { no Estado }\end{array}$ & 2,14 & 0,90 & 1 & 3 \\
\hline $\begin{array}{l}\text { Comparar os pontos de vista dos diferentes atores (comunidade, } \\
\text { trade, turistas, órgãos de governo) da atividade turística }\end{array}$ & 2,00 & 0,82 & 1 & 3 \\
\hline $\begin{array}{l}\text { Aproveitar as ações exitosas, relacionadas ao planejamento } \\
\text { turístico de outras secretarias }\end{array}$ & 2,00 & 0,82 & 1 & 3 \\
\hline $\begin{array}{l}\text { Adaptar as ações exitosas de outras secretarias à realidade de } \\
\text { cada destinação turística }\end{array}$ & 2,00 & 0,82 & 1 & 3 \\
\hline
\end{tabular}

A habilidade para "Reconhecer o turismo como atividade interdependente, visto que, para seu desenvolvimento, são necessárias ações conjuntas com outros segmentos da sociedade" obteve, no grau muito importante, a maioria das respostas dos entrevistados (seis atribuições), enquanto que dois deles afirmaram que esta habilidade é importante. Nenhum dos respondentes atribuiu pouca ou nenhuma importância à referida habilidade.

Com relação à análise do grau de domínio, quatro formuladores pesquisados afirmaram que dominam completamente esta habilidade e três declararam que a dominam quase completamente. Seguindo as respostas atribuídas à dimensão do conhecimento, nenhum dos respondentes declarou dominar pouco ou não dominar esta habilidade.

A análise indica que os formuladores de políticas públicas avaliaram esta habilidade como a terceira mais importante, com média 2,71, e a segunda mais dominada (média 2,57), o que caracteriza a inexistência de lacuna de competência.

Assim como a habilidade anterior, a próxima habilidade ("Reconhecer a atividade turística como global e local, simultaneamente, tendo em vista seu caráter dinâmico e suas especificidades") foi considerada por cinco pesquisados como muito importante e por três como importante. Nenhum formulador atribuiu pouca ou nenhuma importância a esta habilidade.

Do total de pesquisados, todos declararam dominar a referida habilidade, sendo quatro deles totalmente e os outros três quase totalmente. 
Este resultado permite afirmar que esta habilidade foi avaliada como a terceira mais importante (média 2,71), e a segunda mais dominada pelos profissionais pesquisados, com média 2,57. Diante destas respostas, pode-se concluir que esta competência não necessita de ações prioritárias de desenvolvimento.

As habilidades de "Manter bons relacionamentos interpessoais dentro da Setur" e "Manter bons relacionamentos interpessoais no ambiente externo à Setur" receberam as mesmas respostas de importância e de domínio por parte dos formuladores de políticas públicas da Setur. Com relação à importância, seis entrevistados declararam que consideram estas habilidades muito importantes para a realização das atividades inerentes à Setur e apenas um afirmou que estas habilidades são importantes. Não houve quem atribuísse pouca ou nenhuma importância.

Quanto ao grau de domínio, as respostas também ficaram restritas ao domínio completo (cinco pessoas) e ao domínio quase completo (duas).

Estas habilidades apresentaram altas médias de importância $(2,86)$ e de domínio $(2,71)$, sendo classificadas como uma das segundas mais importantes. Quanto ao grau de domínio, as referidas competências estão em primeiro no ranking, evidenciando que não existe necessidade eminente de capacitação com relação a estas habilidades.

"Trabalhar em equipe" é considerada uma habilidade muito importante para a maioria dos entrevistados (seis formuladores) e para um deles é considerada importante. Para esta habilidade, novamente, não houve atribuição de pouca ou nenhuma importância.

No que se refere ao grau de domínio, cinco entrevistados afirmaram que possuem domínio completo sobre esta habilidade, enquanto dois declararam que a dominam quase completamente. Nenhum dos entrevistados declarou possuir pouco ou nenhum domínio sobre "Trabalhar em equipe".

Neste caso, pode-se afirmar que os formuladores consideram esta habilidade como a segunda mais importante, com média 2,86, e uma das primeiras em relação ao grau de domínio declarado pelos profissionais (média 2,71), não necessitando de ações que visem o aprimoramento prioritário da competência.

Para $100 \%$ dos formuladores de políticas públicas da organização, “Trabalhar de forma harmônica e integrada com as diversas áreas da Setur" é uma habilidade muito importante para se atingir os objetivos e alcançar a missão da Setur.

Quanto ao grau de domínio declarado, mais uma vez, cinco entrevistados declararam dominar completamente esta habilidade e os outros dois afirmaram que possuem o quase completo domínio. 
As médias de importância $(3,00)$ e de domínio $(2,71)$ também foram bastante elevadas, classificando-se entre uma das primeiras em suas respectivas escalas. Este resultado indica que não existe necessidade de realizar ações que objetivem desenvolver esta competência.

A habilidade de "Avaliar as políticas públicas executadas por outras secretarias de turismo, pautando-se por uma visão integradora e global" foi avaliada por cinco pesquisados como uma habilidade muito importante e por dois respondentes como uma habilidade importante. Nenhum respondente atribuiu pouca ou nenhuma importância.

$\mathrm{Na}$ escala de domínio, quatro entrevistados declararam que possuem domínio completo sobre a referida habilidade e três afirmaram que possuem o domínio quase total.

Neste caso, a análise indica a inexistência de lacuna de competência, visto que esta habilidade apresentou média de 2,71 em importância, sendo uma das três mais importantes, e média de 2,57 de domínio (classificada entre as segundas mais dominadas pelos profissionais).

“Analisar as políticas públicas da própria Setur-PE, de modo abrangente, mas também de acordo com as especificidades de cada localidade" foi uma das habilidades que todos os formuladores de políticas públicas atribuíram o grau de muito importante.

Com relação ao domínio dos profissionais sobre esta habilidade, observa-se que três entrevistados asseguraram que a dominam completamente, enquanto a maioria (quatro) dos declarou que a domina quase totalmente.

Esta habilidade foi uma das que estão em primeiro na classificação de importância das habilidades identificadas, com média 3,00. Já no grau de domínio, a referida habilidade é uma das terceiras mais dominadas (média 2,43). Este resultado indica que existe uma lacuna de competência, evidenciando a necessidade de ações que priorizem o desenvolvimento da habilidade de "Analisar as políticas públicas da própria Setur-PE, de modo abrangente, mas também de acordo com as especificidades de cada localidade”.

Para seis formuladores de políticas públicas, a habilidade de "Justificar as demandas dos projetos turísticos existentes na Setur com embasamento sócio-político-econômico" foi considerada muito importante. Apenas um entrevistado a considerou importante.

Com relação ao grau de domínio declarado pelos entrevistados, esta habilidade é totalmente dominada por três deles, enquanto quatro respondentes afirmaram que possuem domínio quase completo sobre a referida competência. Nenhum profissional declarou possuir pouco ou nenhum domínio. 
A análise indica que este item foi ordenado como segundo em importância (média 2,86) e como terceiro mais dominado (média 2,43). Assim como a habilidade analisada anteriormente, esta também necessita de ações que objetivem seu desenvolvimento, visto que existe uma discreta lacuna de competência.

As habilidades de "Examinar as situações vivenciadas na Setur com a visão política do contexto" e "Reconhecer oportunidades de negócios, favoráveis à Setur em eventos externos" receberam as mesmas respostas de importância e de domínio por parte dos formuladores de políticas públicas da Setur. Na opinião dos entrevistados, quatro deles as consideram de muita importância; três as avaliaram como importante e nenhum dos profissionais as consideraram pouco ou nada importantes.

Entre os graus de domínio das referidas habilidades, as respostas variaram de domínio completo (duas atribuições); domínio quase completo (quatro); e pouco domínio (uma). Não houve atribuição de nenhum domínio.

Estas habilidades foram consideradas como menos importantes (média 2,57), ocupando o quarto e último lugar no ranking. Com relação ao grau de domínio, as habilidades de "Examinar as situações vivenciadas na Setur com a visão política do contexto" e "Reconhecer oportunidades de negócios, favoráveis à Setur em eventos externos" obtiveram média 2,14, classificando-se como as segundas menos dominadas. Este resultado indica não existir necessidade aprimoramento e capacitação para esta habilidade.

"Identificar oportunidades de desenvolvimento do turismo, por meio dos diferentes tipos da atividade (pedagógico, religioso, de eventos, de lazer)" foi avaliada por quatro pesquisados como uma habilidade muito importante e por três como importante.

Com relação ao grau de domínio, houve variação entre domínio completo e pouco domínio, onde dois pesquisadores declararam que possuem o domínio completo; quatro afirmaram que a dominam quase completamente; e apenas um possui pouco domínio sobre esta habilidade.

A referida habilidade foi julgada pelos profissionais como uma das quatro habilidades que ficaram em último lugar na escala de importância (média 2,57). Com relação ao domínio, a média de 2,14 posicionou esta habilidade também entre as últimas. Portanto, os índices indicam não haver necessidade de maiores aprimoramentos sobre esta habilidade.

A totalidade dos pesquisados avaliou "Identificar novas localidades para a exploração sustentável da atividade turística" como uma habilidade muito importante. 
$\mathrm{Na}$ escala de domínio, quatro profissionais informaram possuir domínio completo, enquanto dois declararam que possuem domínio quase completo sobre a referida competência. Somente um afirmou que possui pouco domínio sobre a referida competência.

Esta habilidade é indicada para ser desenvolvida através das políticas de gestão de pessoas, visto que foi considerada por todos os entrevistados como uma das mais importantes (média 3,00). Em relação ao grau domínio, é a terceira no número de ordem (média 2,43), apresentando um desvio-padrão de 0,79, indicando que houve discrepância entre os graus de domínio dos formuladores de políticas públicas.

A habilidade de "Captar recursos financeiros para o desenvolvimento do turismo no Estado" também foi considerada por $100 \%$ dos formuladores de políticas públicas como muito importante.

Em relação à habilidade anterior, houve uma diferença no que diz respeito aos graus de domínio, onde três pesquisados consideraram que dominam completamente esta competência; dois afirmaram que a dominam quase completamente; e outros dois informaram que possuem pouco domínio. Não houve quem declarasse possuir nenhum domínio.

Considerada por cento por cento dos respondentes como importante, com média 3,00, esta habilidade está entre as quatro primeiras no número de ordem de importância. O baixo grau de domínio apresentado (média 2,14), seguido do elevado desvio padrão $(0,90)$ indicam uma lacuna de competência, evidenciando que esta habilidade é prioridade nas ações de capacitação e desenvolvimento.

Para a grande maioria dos respondentes (seis), a habilidade de "Comparar os pontos de vista dos diferentes atores (comunidade, trade, turistas, órgãos de governo) da atividade turística" é considerada muito importante. Um formulador a considerou importante.

Quanto à análise do grau de domínio, as respostas variaram entre domínio completo (duas atribuições), domínio quase completo (três) e pouco domínio (duas).

Este resultado sugere que existe uma lacuna de competência, visto que esta habilidade apresentou alto grau de importância (média 2,86) e baixo grau de domínio (média 2,00). Nos números de ordem, a referida habilidade classificou-se entre as segundas mais importantes e entre as menos dominadas. 
O desvio-padrão de 0,82 evidencia que houve divergência entre os graus de domínio dos formuladores de políticas públicas da Setur.

As habilidades "Aproveitar as ações exitosas, relacionadas ao planejamento turístico de outras secretarias" e "Adaptar as ações exitosas de outras secretarias à realidade de cada destinação turística" apresentaram resultados idênticos em relação à importância e ao domínio, onde seis formuladores consideraram que estas habilidades são muito importantes e um considerou-a importantes. Não houve atribuição de pouca ou nenhuma importância.

No que se refere ao grau de domínio, houve variação entre domínio completo e pouco domínio. Dois pesquisadores declararam dominar completamente esta habilidade; três afirmaram que a dominam quase completamente; e outros dois informaram que possuem pouco domínio sobre estas habilidades.

Estas habilidades são indicadas para serem desenvolvidas através das políticas de gestão de pessoas, visto que foram consideradas como duas das segundas mais importantes no número de ordem (média 2,86). Em relação ao grau domínio, são duas das últimas no número de ordem (média 2,00), ficando em quinto.

As referidas habilidades apresentaram um desvio-padrão de 0,82 , indicando que houve discrepância entre os graus de domínio dos formuladores de políticas públicas.

\subsection{Atitudes}

A seguir, serão apresentados os dados relativos à dimensão "Atitudes". Na Tabela 9, encontram-se os resultados, em números absolutos e em porcentuais, sobre o grau de importância de cada atitude considerado pelos profissionais pesquisados. O grau de domínio assegurado por eles está expresso na Tabela 10. As médias e os desvios-padrão dos graus de importância e domínio encontram-se tabulados, respectivamente, nas Tabelas 11 e 12.

Tabela 9 - Distribuição do grau de importância das atitudes identificadas.

\begin{tabular}{|c|c|c|c|c|c|c|c|c|}
\hline \multirow{3}{*}{ Ter atitude para } & \multicolumn{6}{|c|}{ Grau de importância } & & \\
\hline & & $\begin{array}{l}\text { â } \\
\text { ância }\end{array}$ & Im & tante & & $\begin{array}{l}\text { ito } \\
\text { tante }\end{array}$ & \multicolumn{2}{|c|}{ TOTAL } \\
\hline & $\mathbf{n}$ & $\%$ & $\mathrm{n}$ & $\%$ & $\mathrm{n}$ & $\%$ & $\mathrm{n}$ & $\%$ \\
\hline $\begin{array}{l}\text { Incluir a comunidade local, no desenvolvimento dos projetos } \\
\text { turísticos }\end{array}$ & - & - & 1 & 14,3 & 6 & 85,7 & 7 & 100,0 \\
\hline
\end{tabular}




\begin{tabular}{|c|c|c|c|c|c|c|c|c|}
\hline $\begin{array}{l}\text { Integrar os diferentes pontos de vista de diversos atores da } \\
\text { atividade turística (comunidade, trade, turistas, órgãos de } \\
\text { governo) }\end{array}$ & - & - & 2 & 28,6 & 5 & 71,4 & 7 & 100,0 \\
\hline $\begin{array}{l}\text { Identificar iniciativas que maximizem os benefícios e condições } \\
\text { favoráveis, advindas da atividade turística para os diversos } \\
\text { atores envolvidos no processo }\end{array}$ & - & - & 2 & 28,6 & 5 & 71,4 & 7 & 100,0 \\
\hline $\begin{array}{l}\text { Primar por escolher ações que Minimizem os impactos } \\
\text { ambientais negativos, causados pelo turismo }\end{array}$ & - & - & 2 & 28,6 & 5 & 71,4 & 7 & 100,0 \\
\hline $\begin{array}{l}\text { Buscar ações que reduzam os impactos culturais negativos, } \\
\text { trazidos pela atividade turística }\end{array}$ & - & - & 1 & 14,3 & 6 & 85,7 & 7 & 100,0 \\
\hline $\begin{array}{l}\text { Procurar mecanismos que atenuem os impactos negativos sócio- } \\
\text { econômicos, em decorrência do turismo }\end{array}$ & - & - & 1 & 14,3 & 6 & 85,7 & 7 & 100,0 \\
\hline Realizar, periodicamente, pesquisas com os atores da atividade & - & - & 2 & 28,6 & 5 & 71,4 & 7 & 100,0 \\
\hline $\begin{array}{l}\text { Divulgar o trabalho executado pela Setur para os diferentes } \\
\text { atores da atividade }\end{array}$ & - & - & - & - & 7 & 100,0 & 7 & 100,0 \\
\hline $\begin{array}{l}\text { Atuar em conjunto com as demais entidades, empresas e } \\
\text { secretarias (Educação, Segurança, Defesa Social, Cultura e Meio } \\
\text { Ambiente) do Estado e do Brasil }\end{array}$ & - & - & 2 & 28,6 & 5 & 71,4 & 7 & 100,0 \\
\hline Ser proativo diante das situações vivenciadas na Setur & - & - & - & - & 7 & 100,0 & 7 & 100,0 \\
\hline Atuar de forma ética, frente à sociedade e ao meio-ambiente & - & - & - & - & 7 & 100,0 & 7 & 100,0 \\
\hline $\begin{array}{l}\text { Agir com responsabilidade, frente à sociedade e ao meio- } \\
\text { ambiente }\end{array}$ & - & - & - & - & 7 & 100,0 & 7 & 100,0 \\
\hline
\end{tabular}

Tabela 10 - Distribuição do grau de domínio das atitudes identificadas.

\begin{tabular}{|c|c|c|c|c|c|c|c|c|}
\hline \multirow{3}{*}{ Ter atitude para } & \multicolumn{8}{|c|}{ Grau de domínio } \\
\hline & \multicolumn{2}{|c|}{$\begin{array}{c}\text { Pouco } \\
\text { domínio }\end{array}$} & \multicolumn{2}{|c|}{$\begin{array}{l}\text { Domínio } \\
\text { quase } \\
\text { completo }\end{array}$} & \multicolumn{2}{|c|}{$\begin{array}{l}\text { Domínio } \\
\text { completo }\end{array}$} & \multicolumn{2}{|c|}{ TOTAL } \\
\hline & $\mathbf{n}$ & $\%$ & $\mathbf{n}$ & $\%$ & $\mathbf{n}$ & $\%$ & $\mathbf{n}$ & $\%$ \\
\hline $\begin{array}{l}\text { Incluir a comunidade local, no desenvolvimento dos projetos } \\
\text { turísticos }\end{array}$ & - & - & 4 & 57,1 & 3 & 42,9 & 7 & 100,0 \\
\hline $\begin{array}{l}\text { Integrar os diferentes pontos de vista de diversos atores da } \\
\text { atividade turística (comunidade, trade, turistas, órgãos de } \\
\text { governo) }\end{array}$ & 2 & 28,6 & 3 & 42,9 & 2 & 28,6 & 7 & 100,0 \\
\hline $\begin{array}{l}\text { Identificar iniciativas que maximizem os benefícios e condições } \\
\text { favoráveis, advindas da atividade turística para os diversos } \\
\text { atores envolvidos no processo }\end{array}$ & 2 & 28,6 & 3 & 42,9 & 2 & 28,6 & 7 & 100,0 \\
\hline $\begin{array}{l}\text { Primar por escolher ações que Minimizem os impactos } \\
\text { ambientais negativos, causados pelo turismo }\end{array}$ & 1 & 14,3 & 4 & 57,1 & 2 & 28,6 & 7 & 100,0 \\
\hline $\begin{array}{l}\text { Buscar ações que reduzam os impactos culturais negativos, } \\
\text { trazidos pela atividade turística }\end{array}$ & 1 & 14,3 & 4 & 57,1 & 2 & 28,6 & 7 & 100,0 \\
\hline $\begin{array}{l}\text { Procurar mecanismos que atenuem os impactos negativos sócio- } \\
\text { econômicos, em decorrência do turismo }\end{array}$ & 1 & 14,3 & 4 & 57,1 & 2 & 28,6 & 7 & 100,0 \\
\hline Realizar, periodicamente, pesquisas com os atores da atividade & - & - & 5 & 71,4 & 2 & 28,6 & 7 & 100,0 \\
\hline $\begin{array}{l}\text { Divulgar o trabalho executado pela Setur para os diferentes } \\
\text { atores da atividade }\end{array}$ & - & - & 5 & 71,4 & 2 & 28,6 & 7 & 100,0 \\
\hline
\end{tabular}




\begin{tabular}{|c|c|c|c|c|c|c|c|c|}
\hline $\begin{array}{l}\text { Atuar em conjunto com as demais entidades, empresas e } \\
\text { secretarias (Educação, Segurança, Defesa Social, Cultura e Meio } \\
\text { Ambiente) do Estado e do Brasil }\end{array}$ & 2 & 28,6 & 4 & 57,1 & 1 & 14,3 & 7 & 100,0 \\
\hline Ser proativo diante das situações vivenciadas na Setur & - & - & 4 & 57,1 & 3 & 42,9 & 7 & 100,0 \\
\hline Atuar de forma ética, frente à sociedade e ao meio-ambiente & - & - & 4 & 57,1 & 3 & 42,9 & 7 & 100,0 \\
\hline $\begin{array}{l}\text { Agir com responsabilidade, frente à sociedade e ao meio- } \\
\text { ambiente }\end{array}$ & - & - & 4 & 57,1 & 3 & 42,9 & 7 & 100,0 \\
\hline
\end{tabular}

Tabela 11 - Média e desvio-padrão do grau de importância das atitudes identificadas.

\begin{tabular}{|c|c|c|c|c|}
\hline \multirow[b]{2}{*}{ Ter atitude para } & \multicolumn{4}{|c|}{ Estatísticas } \\
\hline & Média & $\begin{array}{l}\text { Desvio } \\
\text { padrão }\end{array}$ & Mínimo & Máximo \\
\hline $\begin{array}{l}\text { Incluir a comunidade local, no desenvolvimento dos projetos } \\
\text { turísticos }\end{array}$ & 2,86 & 0,38 & 2 & 3 \\
\hline $\begin{array}{l}\text { Integrar os diferentes pontos de vista de diversos atores da } \\
\text { atividade turística (comunidade, trade, turistas, órgãos de } \\
\text { governo) }\end{array}$ & 2,71 & 0,49 & 2 & 3 \\
\hline $\begin{array}{l}\text { Identificar iniciativas que maximizem os benefícios e condições } \\
\text { favoráveis, advindas da atividade turística para os diversos } \\
\text { atores envolvidos no processo }\end{array}$ & 2,71 & 0,49 & 2 & 3 \\
\hline $\begin{array}{l}\text { Primar por escolher ações que Minimizem os impactos } \\
\text { ambientais negativos, causados pelo turismo }\end{array}$ & 2,71 & 0,49 & 2 & 3 \\
\hline $\begin{array}{l}\text { Buscar ações que reduzam os impactos culturais negativos, } \\
\text { trazidos pela atividade turística }\end{array}$ & 2,86 & 0,38 & 2 & 3 \\
\hline $\begin{array}{l}\text { Procurar mecanismos que atenuem os impactos negativos sócio- } \\
\text { econômicos, em decorrência do turismo }\end{array}$ & 2,86 & 0,38 & 2 & 3 \\
\hline Realizar, periodicamente, pesquisas com os atores da atividade & 2,71 & 0,49 & 2 & 3 \\
\hline $\begin{array}{l}\text { Divulgar o trabalho executado pela Setur para os diferentes } \\
\text { atores da atividade }\end{array}$ & 3,00 & 0,00 & 3 & 3 \\
\hline $\begin{array}{l}\text { Atuar em conjunto com as demais entidades, empresas e } \\
\text { secretarias (Educação, Segurança, Defesa Social, Cultura e Meio } \\
\text { Ambiente) do Estado e do Brasil }\end{array}$ & 2,71 & 0,49 & 2 & 3 \\
\hline Ser proativo diante das situações vivenciadas na Setur & 3,00 & 0,00 & 3 & 3 \\
\hline Atuar de forma ética, frente à sociedade e ao meio-ambiente & 3,00 & 0,00 & 3 & 3 \\
\hline $\begin{array}{l}\text { Agir com responsabilidade, frente à sociedade e ao meio- } \\
\text { ambiente }\end{array}$ & 3,00 & 0,00 & 3 & 3 \\
\hline
\end{tabular}

Tabela 12 - Média e desvio-padrão do grau de domínio das atitudes identificadas.

\begin{tabular}{l|c|c|c}
\hline \multicolumn{3}{|c}{ Estatísticas } \\
\hline Ter atitude para & Média & $\begin{array}{c}\text { Desvio } \\
\text { padrão }\end{array}$ & Mínimo \\
\hline $\begin{array}{l}\text { Incluir a comunidade local, no desenvolvimento dos projetos } \\
\text { turísticos }\end{array}$ & 2,43 & 0,54 & 2 \\
\hline
\end{tabular}




\begin{tabular}{|c|c|c|c|c|}
\hline $\begin{array}{l}\text { Integrar os diferentes pontos de vista de diversos atores da } \\
\text { atividade turística (comunidade, trade, turistas, órgãos de } \\
\text { governo) }\end{array}$ & 2,00 & 0,82 & 1 & 3 \\
\hline $\begin{array}{l}\text { Identificar iniciativas que maximizem os benefícios e condições } \\
\text { favoráveis, advindas da atividade turística para os diversos } \\
\text { atores envolvidos no processo }\end{array}$ & 2,00 & 0,82 & 1 & 3 \\
\hline $\begin{array}{l}\text { Primar por escolher ações que Minimizem os impactos } \\
\text { ambientais negativos, causados pelo turismo }\end{array}$ & 2,14 & 0,69 & 1 & 3 \\
\hline $\begin{array}{l}\text { Buscar ações que reduzam os impactos culturais negativos, } \\
\text { trazidos pela atividade turística }\end{array}$ & 2,14 & 0,69 & 1 & 3 \\
\hline $\begin{array}{l}\text { Procurar mecanismos que atenuem os impactos negativos sócio- } \\
\text { econômicos, em decorrência do turismo }\end{array}$ & 2,14 & 0,69 & 1 & 3 \\
\hline $\begin{array}{l}\text { Realizar, periodicamente, pesquisas com os atores da atividade } \\
\text { Divulgar o trabalho executado pela Setur para os diferentes } \\
\text { atores da atividade }\end{array}$ & $\begin{array}{l}2,29 \\
2,29\end{array}$ & 0,49 & 2 & 3 \\
\hline $\begin{array}{l}\text { Atuar em conjunto com as demais entidades, empresas e } \\
\text { secretarias (Educação, Segurança, Defesa Social, Cultura e Meio } \\
\text { Ambiente) do Estado e do Brasil }\end{array}$ & 1,86 & 0,69 & 1 & 3 \\
\hline Ser proativo diante das situações vivenciadas na Setur & 2,43 & 0,54 & 2 & 3 \\
\hline Atuar de forma ética, frente à sociedade e ao meio-ambiente & 2,43 & 0,54 & 2 & 3 \\
\hline $\begin{array}{l}\text { Agir com responsabilidade, frente à sociedade e ao meio- } \\
\text { ambiente }\end{array}$ & 2,43 & 0,54 & 2 & 3 \\
\hline
\end{tabular}

"Incluir a comunidade local, no desenvolvimento dos projetos turísticos" foi uma atitude considerada por seis entrevistados como muito importante e apenas um considerou-a importante.

No que refere ao grau de domínio, três formuladores de políticas públicas informaram que possuem domínio completo sobre a referida atitude, enquanto quatro declararam que a dominam quase completamente.

Esta atitude apresentou média de 2,86, sendo classificada como uma das segundas mais importantes. Quanto ao grau de domínio, a referida competência está em primeiro no ranking (média 2,43), evidenciando que existe uma discreta lacuna de competência.

Para cinco respondentes, as atitudes de "Integrar os diferentes pontos de vista de diversos atores da atividade turística (comunidade, trade, turistas, órgãos de governo)" e de "Identificar iniciativas que maximizem os benefícios e condições favoráveis, advindas da atividade turística para os diversos atores envolvidos no processo" são consideradas muito importantes; para dois deles as referidas atitudes foram avaliadas como importantes. 
Quanto ao grau de domínio, dois formuladores pesquisados informaram possuir domínio completo; três, domínio quase completo; e outros dois declaram que possuem pouco domínio sobre as atitudes mencionadas.

Este resultado sugere que existe uma lacuna de competência, visto que estas atitudes apresentaram relativo grau de importância (média 2,71) e baixo grau de domínio (média 2,00). Nos números de ordem, a referida atitude classificou-se entre as terceiras mais importantes e entre as menos dominadas (quarta posição no número de ordem).

O desvio-padrão de 0,82 evidencia que houve divergência entre os graus de domínio dos formuladores de políticas públicas da Setur.

A atitude de "Primar por escolher ações que minimizem os impactos ambientais negativos, causados pelo turismo" obteve, no grau muito importante, a maioria das respostas dos entrevistados (cinco pesquisados), enquanto dois deles afirmaram que esta atitude é importante. Nenhum dos respondentes atribuiu pouca ou nenhuma importância à referida atitude.

Com relação ao grau de domínio declarado pelos formuladores, dois informaram dominar completamente esta atitude; quatro declararam que a dominam quase completamente; e um afirmou que possui pouco domínio. Ninguém afirmou não dominar a referida atitude.

Da relação entre os graus de importância e de domínio, conclui-se que os respondentes atribuíram importância a esta atitude (média 2,71), sendo classificada como uma das terceiras mais importantes, e relativo domínio, com média de 2,14 e terceiro no número de ordem. Esta constatação indica que existe uma pequena lacuna de competências e que esta atitude pode ser melhor desenvolvida entre os formuladores de políticas públicas da Setur, para o efetivo desenvolvimento das atividades da organização.

As atitudes de "Buscar ações que reduzam os impactos culturais negativos, trazidos pela atividade turística" e de "Procurar mecanismos que atenuem os impactos negativos sócio-econômicos, em decorrência do turismo" receberam idênticas avaliações com relação aos graus de importância e de domínio. Para seis pesquisados, estas atitudes possuem muita importância, enquanto somente um considerou-as importantes.

Os graus de domínio variaram entre domínio completo e pouco domínio, sendo que dois formuladores declararam que possuem domínio completo; quatro deles informaram que dominam estas atitudes quase completamente; e um declarou que possui pouco domínio sobre as referidas atitudes. 
Estas atitudes são indicadas para serem desenvolvidas através das políticas de gestão de pessoas que visem à diminuição nas lacunas de competências, visto que foram consideradas como duas das segundas mais importantes no número de ordem (média 2,86). Em relação ao grau domínio, obtiveram média de 2,14 e, no número de ordem, estão classificadas em terceiro.

"Realizar, periodicamente, pesquisas com os atores da atividade" foi considerada por cinco pesquisados como uma atitude importante. Já os outros dois atribuíram a esta competência o grau de importante.

Ainda com base na análise, dois respondentes afirmaram possuir domínio completo e os outros cinco declararam que dominam quase completamente a referida atitude.

Apesar de ter sido considerada como uma das menos importantes, com média de 2,71, esta habilidade apresentou relativo baixo grau de domínio (média 2,29) e pode ser apontada para ser aprimorada em ações de desenvolvimento e capacitação.

$\mathrm{Na}$ opinião de todos os pesquisados, "Divulgar o trabalho executado pela Setur para os diferentes atores da atividade" é uma atitude muito importante. Com relação ao grau de domínio, dois acham que a dominam completamente, enquanto cinco declararam que possuem domínio quase completo.

Neste caso, existe uma lacuna de competência, visto que, apesar de ter sido ordenada como uma das primeiras em importância (média 3,00) e como uma das segundas em domínio (média 2,29), pela análise, esta atitude deve ser melhor desenvolvida através da política de gestão de pessoas da Setur.

A análise dos dados indica que, para cinco entrevistados, a atitude de "Atuar em conjunto com as demais entidades, empresas e secretarias (Educação, Segurança, Defesa Social, Cultura e Meio Ambiente) do Estado e do Brasil” é considerada muito importante. O número de entrevistados que a considera importante são dois.

Quanto ao domínio, as respostas variam entre domínio completo (uma atribuição); domínio quase completo (quatro) e; pouco domínio (duas). Ninguém afirmou não dominar a referida atitude.

Este resultado constata que existe uma lacuna de competência, visto que esta atitude apresentou relativo grau de importância (média 2,71) e baixo grau de domínio (média 1,86). Nos números de ordem, a referida atitude classificou-se entre as terceiras mais importantes e entre as menos dominadas (quinta posição no número de ordem). 
As atitudes de "Ser proativo diante das situações vivenciadas na Setur", de "Atuar de forma ética, frente à sociedade e ao meio-ambiente" e de "Agir com responsabilidade, frente à sociedade e ao meio-ambiente" receberam atribuições idênticas em relação aos graus de importância e de domínio. A totalidade dos formuladores de políticas públicas da Setur considerou estas atitudes muito importantes.

No que se refere ao domínio, três pesquisados afirmaram que as dominam completamente e os outros quatro declararam possuir domínio quase completo sobre as referidas atitudes.

Por fim, com médias de 3,00 e de 2,43 para os graus de importância e de domínio, respectivamente, a análise indica uma lacuna de competência, visto que, a referida competência é considerada demasiado importante e seu domínio não é completo.

Da análise dos dados extraídos do questionário, em suma, pode-se afirmar que todas as habilidades e todas as atitudes foram classificadas como muito importante ou importante.

Dentre os conhecimentos que apresentaram menor grau de importância encontram-se a Comunicação em língua inglesa, na forma oral, com fluência; a Comunicação em língua inglesa, na forma escrita, com fluência; a Comunicação em língua espanhola, na forma oral, com fluência e; a Comunicação em língua espanhola, na forma escrita, com fluência.

Com relação ao domínio declarado pelos pesquisados, ressalta-se que todas as atitudes apresentaram relativo baixo grau de domínio, enquanto a dimensão conhecimentos apresentou as maiores médias com domínio completo e com domínio quase completo.

Portanto, foram encontradas lacunas de competências nos seguintes conhecimentos: Legislação relativa à atividade turística, aplicável às atividades desenvolvidas; Técnicas de elaboração de projetos turísticos; Técnicas de divulgação das destinações turísticas e; Técnicas de promoção das destinações turísticas.

No que re refere às habilidades, verificou-se que existe a necessidade de desenvolvimento entre sete competências (Analisar as políticas públicas da própria Setur-PE, de modo abrangente, mas também de acordo com as especificidades de cada localidade; Justificar as demandas dos projetos turísticos existentes na Setur com embasamento sóciopolítico-econômico; Identificar novas localidades para a exploração sustentável da atividade turística; Captar recursos financeiros para o desenvolvimento do turismo no Estado; Comparar os pontos de vista dos diferentes atores (comunidade, trade, turistas, órgãos de governo) da atividade turística; Aproveitar as ações exitosas, relacionadas ao planejamento turístico de outras secretarias e; Adaptar as ações exitosas de outras secretarias à realidade de cada destinação turística). 
Tendo em vista que todas as atitudes apresentaram baixo grau de domínio, verificou-se que existe uma lacuna de competência que necessita ser diminuída para o efetivo desenvolvimento das atividades da Setur e para o alcance da missão e dos objetivos da organização. Estas lacunas de competências podem ser reduzidas por meio de ações de desenvolvimento e capacitação, executadas por meio da política de gestão de pessoas baseada na gestão por competências.

Com relação aos desvios-padrão, em termos de importância, aqueles conhecimentos que apresentaram maior índice $(0,79)$ foram a Comunicação em língua inglesa, na forma oral, com fluência; a Comunicação em língua inglesa, na forma escrita, com fluência; a Comunicação em língua espanhola, na forma oral, com fluência e; a Comunicação em língua espanhola, na forma escrita, com fluência.

Nenhuma habilidade e nenhuma atitude apresentaram desvio-padrão elevado, concluindo-se que houve convergência de opiniões entre os formuladores pesquisados.

Com relação ao grau de domínio, os conhecimentos que apresentaram os maiores desvio-padrão também foram a Comunicação em língua espanhola, na forma oral, com fluência e a Comunicação em língua espanhola, na forma escrita, com fluência, acrescidos das Técnicas de elaboração de projetos turísticos; Técnicas de divulgação das destinações turísticas; Técnicas de promoção das destinações turísticas; Atribuições da Setur e; Limites de atuação da Setur.

No que se refere às habilidades, Captar recursos financeiros para o desenvolvimento do turismo no Estado (0,90); Comparar os pontos de vista dos diferentes atores (comunidade, trade, turistas, órgãos de governo) da atividade turística $(0,82)$; Aproveitar as ações exitosas, relacionadas ao planejamento turístico de outras secretarias $(0,82)$ e; Adaptar as ações exitosas de outras secretarias à realidade de cada destinação turística $(0,82)$ foram as que obtiveram os maiores índices de desvios-padrão.

As atitudes de Integrar os diferentes pontos de vista de diversos atores da atividade turística (comunidade, trade, turistas, órgãos de governo) e Identificar iniciativas que maximizem os benefícios e condições favoráveis, advindas da atividade turística para os diversos atores envolvidos no processo apresentaram desvio-padrão de 0,82.

Assim, estas competências apresentaram divergência de opinião entre os pesquisados.

A seguir, serão apresentadas as conclusões finais baseadas no marco teórico e na análise dos dados coletados no decorrer da pesquisa. 


\section{CONCLUSÕES}

A presente pesquisa teve como objetivo principal a identificação das competências necessárias aos profissionais formuladores de políticas públicas da Secretaria de Turismo de Pernambuco, que atuam nas áreas de Fomento, de Articulação e de Empreendimentos Turísticos e na Secretaria Executiva.

O referido objetivo geral foi detalhado através dos objetivos específicos de identificar a missão, os objetivos e os desafios a serem enfrentados pela organização, bem como analisar as competências necessárias aos profissionais formuladores das políticas públicos da Setur. Após a identificação destas competências, buscou-se verificar o grau de importância e grau de domínio que os pesquisados apresentam em relação aos conhecimentos, habilidades e atitudes para, então, elencar possíveis lacunas entre as competências existentes e as necessárias à consecução dos objetivos e atribuições da Setur.

Para o alcance dos objetivos propostos, primeiramente, foi realizada uma análise documental entre decretos, planejamento estratégico, plano diretor e outros documentos próprios da organização estudada, onde se conclui que a missão da Secretaria de Turismo de Pernambuco é planejar e executar a política de turismo no Estado, estimulando o desenvolvimento dos diversos segmentos da atividade e estabelecendo parcerias com a iniciativa privada, com a comunidade e com as outras organizações turísticas do Estado, do Brasil e do exterior. Também é missão da Setur fomentar ações e programas de implantação de empreendimentos estruturadores do turismo no Estado.

Dentre os valores identificados na organização estão responsabilidade social e ambiental, integridade, trabalho em equipe, respeito à comunidade autóctone, ética, valorização do ser humano e qualidade dos serviços.

Por meio da entrevista individual, realizada com a Assessora do Governador e também Gestora de Fomento, pode-se afirmar que os principais desafios, enfrentados pela Setur e pelos formuladores de políticas públicas, são:

- incluir e manter o turismo na pauta de política pública prioritária do Governo do Estado de Pernambuco, visto que, para se desenvolver, a atividade precisa de apoio e de investimentos governamentais e não-governamentais; e

- ter consciência dos procedimentos e da visão política do contexto, tendo em vista que não é suficiente que os formuladores saibam os aspectos teóricos, técnicos e práticos inerentes ao turismo, mas eles também devem atuar entre atividade política e a atividade turística. 
Ainda por meio da técnica da entrevista individual, com o objetivo de elencar e descrever as competências mencionadas, foram identificados 19 conhecimentos, 17 habilidades e 12 atitudes necessárias aos formuladores de políticas públicas da Setur.

Da análise dos dados, verificou-se que todas as 48 competências identificadas foram consideradas importantes pelos pesquisados, enquanto que 23 delas apresentaram relativo baixo grau de domínio, evidenciando-se a existência de lacunas, sendo:

a) quatro na dimensão conhecimentos: Legislação relativa à atividade turística, aplicável às atividades desenvolvidas; Técnicas de elaboração de projetos turísticos; Técnicas de divulgação das destinações turísticas e; Técnicas de promoção das destinações turísticas.

b) sete em habilidades: Analisar as políticas públicas da própria Setur-PE, de modo abrangente, mas também de acordo com as especificidades de cada localidade; Justificar as demandas dos projetos turísticos existentes na Setur com embasamento sócio-político-econômico; Identificar novas localidades para a exploração sustentável da atividade turística; Captar recursos financeiros para o desenvolvimento do turismo no Estado; Comparar os pontos de vista dos diferentes atores (comunidade, trade, turistas, órgãos de governo) da atividade turística; Aproveitar as ações exitosas, relacionadas ao planejamento turístico de outras secretarias e; Adaptar as ações exitosas de outras secretarias à realidade de cada destinação turística

c) doze em atitudes, configurando sua totalidade: Incluir a comunidade local, no desenvolvimento dos projetos turísticos; Integrar os diferentes pontos de vista de diversos atores da atividade turística (comunidade, trade, turistas, órgãos de governo); Identificar iniciativas que maximizem os benefícios e condições favoráveis, advindas da atividade turística para os diversos atores envolvidos no processo; Primar por escolher ações que minimizem os impactos ambientais negativos, causados pelo turismo; Buscar ações que reduzam os impactos culturais negativos, trazidos pela atividade turística; Procurar mecanismos que atenuem os impactos negativos sócioeconômicos, em decorrência do turismo; Realizar, periodicamente, pesquisas com os atores da atividade; Divulgar o trabalho executado pela Setur para os diferentes atores da atividade; Atuar em conjunto com as demais entidades, empresas e secretarias (Educação, Segurança, Defesa Social, Cultura e Meio-Ambiente) do Estado e do Brasil; Ser proativo diante das situações vivenciadas na Setur; Atuar de forma ética, frente à sociedade e ao meio-ambiente e; Agir com responsabilidade, frente à sociedade e ao meio-ambiente. 
O presente estudo, no decorrer da pesquisa, mostrou-se relevante, visto que, a partir dos dados coletados e analisados através do questionário, foi possível identificar, na perspectiva do formulador de políticas públicas da Setur, o grau de importância e o grau de domínio dos conhecimentos, das habilidades e das atitudes relevantes para seus desempenhos, bem como identificar as lacunas de competências existentes na organização. Destarte, os resultados obtidos podem ser utilizados para subsidiar o desenvolvimento da política de Gestão de Pessoas da Setur e, mais especificamente, para embasar os procedimentos de capacitação dos profissionais.

Para estes profissionais, a ciência sobre as competências necessárias à formulação de políticas públicas do turismo pode auxiliar no desenvolvimento de trilhas de aprendizagem, pessoal e profissional, e no suprimento das demandas do trabalho, no intuito de gerar resultados positivos no desempenho de suas atribuições, bem como o aprimoramento constante dos conhecimentos, das habilidades e das atitudes necessárias ao efetivo desenvolvimento das atividades da organização.

Portanto, conclui-se que os profissionais devem incorporar competências ou aperfeiçoar aquelas que já dominam, dentro do contexto e da vivência no ambiente de trabalho, tendo em vista que indivíduos capacitados estão constantemente modificando as competências e adquirindo novas formas de agir, de pensar e de posicionar-se em sua atividade profissional.

De qualquer forma, ressalta-se que as competências que interessam a uma organização são, elas mesmas, mutáveis ao longo do tempo, existindo a permanente necessidade de manter atualizado o inventário das competências encontradas na organização, a fim de atingir os objetivos e a estratégia organizacionais.

Por fim, o estudo iniciado na presente pesquisa não se esgota aqui, podendo ter continuidade, por exemplo, para verificar com qual freqüência os formuladores de políticas públicas utilizam os conhecimentos, as habilidades ou as atitudes identificadas. Tal enfoque poderia ser empregado para o planejamento de ações que visem à realização de treinamentos, cursos e outras ações de capacitação e desenvolvimento.

Este estudo também pode servir para embasar possíveis futuras alterações nos objetivos e nas estratégias organizacional, no intuito de se verificar o que já existe e o que necessita ser criado e aprimorado para o desenvolvimento do turismo em Pernambuco. 


\section{REFERÊNCIAS}

BARROS, Aidil Jesus da Silveira; LEHFELD, Neide Aparecida de Souza. Fundamentos de metodologia científica: um guia para a iniciação científica. 2. ed. São Paulo: Makron, 2000.

BARRETTO, Margarita. O imprescindível aporte das ciências sociais para o planejamento e a compreensão do turismo. Caxias do Sul: Universidade de Caxias do Sul, 2003.

BARRETTO, Margarita; BURGOS, Raúl; FRENKEL, David. Turismo, políticas públicas e relações internacionais. Campinas: Papirus, 2003.

BENI, Mário Carlos. Análise estrutural do turismo. 4. ed. São Paulo: SENAC, 2001.

BRANDÃO, Hugo Pena; BAHRY, Carla Patrícia. Gestão por competências: métodos e técnicas para mapeamento de competências. Revista do Serviço Público, Brasília, 56 (2), p. 179-194. abr./jun., 2005.

BRANDÃO, Hugo Pena; GUIMARÃES, Tomás de Aquino. Gestão de Competências e Gestão de Desempenho: tecnologias distintas ou instrumentos de um mesmo construto? Revista de Administração de Empresas, São Paulo, v. 41, n. 1, p. 8-15. jan./mar., 2001.

BRANDÃO, Hugo Pena. Competências no trabalho: uma análise da produção científica brasileira. Estudos de Psicologia. vol 12 (2). p. 149-158. ago, 2007.

BRUNO-FARIA, Maria de Fátima; BRANDÃO, Hugo Pena. Competências Relevantes a Profissionais da Área de T\&D de uma Organização Pública do Distrito Federal. Revista de Administração Contemporânea, Rio de Janeiro, v. 7, n. 3, p. 35-56. jul./set., 2003.

CARBONE, Pedro Paulo; BRANDÃO, Hugo Pena; LEITE, João Batista Diniz; VILHENA, Rosa Maria de Paula. Gestão por competências e gestão do conhecimento. 2. ed. Rio de Janeiro: FGV, 2006.

CARDOSO-FILHO, Jair Cunha. Identificação de competências individuais em atividade de fiscalização e controle externo na Câmara Legislativa do Distrito Federal. Dissertação de Mestrado - Universidade de Brasília, Brasília, 2003.

CHIAVENATO, Idalberto. Recursos humanos. 7. ed., Atlas, 2002.

COOPER, C.; FLETCHER, J.; WANHILL, S.; GILBERT, D.; SHEPHERD, R. Turismo: princípios e prática. 2. ed. Porto Alegre: Bookman, 2001.

DUTRA, Joel Souza; HIPÓLITO, J. A. Monteiro; SILVA, C. Machado. Gestão de pessoas por competências: o caso de uma empresa do setor de telecomunicações. Revista de Administração Contemporânea, v. 4. n. 1, p. 161-176, Jan./Abr. 2000.

DUTRA, Joel Souza. Gestão de competências: um modelo avançado para o gerenciamento de pessoas. São Paulo: Editora Gente, 2001. 
DUTRA, Joel Souza. Competências: conceitos e instrumentos para a gestão de pessoas na empresa moderna. São Paulo: Atlas, 2004.

FLEURY, Afonso; FLEURY, Maria Tereza Leme. Estratégias empresariais e formação de competências: um quebra-cabeça caleidoscópico da indústria brasileira. 3. ed. São Paulo: Atlas, 2004.

GUIMARÃES, Tomás de Aquino; BRUNO-FARIA, Maria de Fátima; BRANDÃO, Hugo Pena. Aspectos metodológicos do diagnóstico de competências em organizações. In: BORGES-ANRADE, Jairo E.; ABBAD, Gardênia da Silva; MOURÃO, Luciana (Org.). Treinamento, desenvolvimento e educação em organizações e trabalho: fundamentos para a gestão de pessoas. Porto Alegre: Artmed, 2006. p. 216-230.

GUNN, C. A.. Vacation scape: the design of travel environments. 2 ed. London: Van Norstrand, Reinhold, 1988.

IGNARA, Luiz Renato. Fundamentos do turismo. 2. ed. São Paulo: Pioneira Thompson Learning, 2001.

KOTLER, P.; ARMSTRONG, G. Princípios de marketing. 9. ed. São Paulo: Prentice-Hall, 2003.

LIMA, Suzana M. Valle; BORGES-ANDRADE, Jairo E. Bases conceituais e teóricas de avaliação de necessidades em TD\&E. In: BORGES-ANRADE, Jairo E.; ABBAD, Gardênia da Silva; MOURÃO, Luciana (Org.). Treinamento, desenvolvimento e educação em organizações e trabalho: fundamentos para a gestão de pessoas. Porto Alegre: Artmed, 2006. p. 199-215.

MALHOTRA, Naresh. Pesquisa de marketing: uma orientação aplicada. 3. ed. Porto Alegre: Bookman, 2001.

MOTTA, P. R. Transformação organizacional: a teoria e a prática de inovar. Rio de Janeiro: Qualitymark, 1998.

OMT. Introdução ao turismo. São Paulo: Roca, 2001.

PERNAMBUCO. Decreto $\mathrm{n}^{\mathrm{o}}$ 29.508, de 3 de agosto de 2006. Aprova o Regulamento da Secretaria de Turismo, e dá outras providências. Diário Oficial do Estado de Pernambuco, Recife, 4 de agosto de 2006.

PIMENTA, Maria Alzira. Gestão de pessoas em turismo: sustentabilidade, qualidade e comunicação. 2. ed. Campinas: Alínea, 2006.

RABAGLIO, Maria Odete. Seleção por competência. Ed. Educador, 2001.

RICHARDSON, Roberto Jarry. Pesquisa social: métodos e técnicas. 3. ed. Rev. Ampl. São Paulo: Atlas, 1999. 
SANTOS, Armando Cuesta. O uso do método Delphi na criação de um modelo de competências. Revista de Administração de Empresas, São Paulo, v.36, n.2, p. 25-32, abr./jun., 2001.

SANTOS, Izaquias Estevam dos. Manual de métodos e técnicas da pesquisa científica. 5 . ed. Rev. Ampl. Rio de Janeiro: Impetus, 2005.

ULRICH, D. Os campeões de recursos humanos: inovando para obter os melhores resultados. São Paulo: Futura, 1998.

VERGARA, Sylvia Constant. Projetos e relatórios de pesquisa em administração. 3. ed. São Paulo: Atlas, 2000.

ZABOT, J. B. M.; SILVA, L. C. M.; Gestão do conhecimento: aprendizagem e tecnologia construindo a inteligência coletiva. Editora Atlas: São Paulo, 2002.

ZARIFIAN, Philippe. Objetivo competência: por uma nova lógica. São Paulo: Atlas, 2001. 
APÊNDICES 


\section{APÊNDICE I}

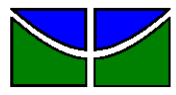

Universidade de Brasília

Faculdade de Economia, Administração, Contabilidade e Ciência da Informação e Documentação

Programa de Pós-Graduação em Administração

Curso Especialização em Gestão de Pessoas

Fernanda Carneiro de Andrade Lima

IDENTIFICAÇÃO DE COMPETÊNCIAS NECESSÁRIAS AOS PROFISSIONAIS FORMULADORES DE POLÍTICAS

PÚBLICAS DA SECRETARIA DE TURISMO DE PERNAMBUCO

\section{ROTEIRO DE ENTREVISTA}

\section{COMPETENCIAS ORGANIZACIONAIS}

De acordo com Fleury e Fleury (2004), assim como os indivíduos desenvolvem competências percebidas como conjuntos de conhecimentos, habilidades e atitudes, as organizações também desenvolvem competências que contribuem para o desempenho de suas atividades de negócio, considerando-se tanto os conhecimentos adquiridos com a experiência da organização, como também os valores que a empresa defende e o processo de interação entre as pessoas que a compõem. A organização poderia ser vista, então, como um portfólio de competências.

Segundo Murray (2003 apud LIMA; BORGES-ANDRADE, 2006), competências organizacionais são definidas por processos, sistemas e práticas, que habilitam uma organização a transformar capacidades pessoais em competências organizacionais como um todo.

\section{COMPETENNCIAS INDIVIDUAIS}

De acordo com Durand (1999 apud CARDOSO FILHO, 2003), o conceito de competência baseia-se em três dimensões:

IV. Conhecimento: diz respeito ao saber acumulado pela pessoa ao longo da vida, correspondendo a uma série de informações assimiladas e estruturadas pelo indivíduo, que lhe permitem entender o mundo;

V. Habilidade: relaciona-se à capacidade de aplicar e fazer uso produtivo do conhecimento, utilizando-o em uma ação para o alcance de um objetivo específico; 
VI. Atitude: relaciona-se a aspectos sociais e afetivos associados ao trabalho, implicando um sentimento, uma emoção ou um grau de aceitação ou rejeição do indivíduo em relação aos outros.

Para Zarifian (2001), o bom profissional incorpora competências ou aperfeiçoa aquelas que já domina, dentro do contexto e da vivência no ambiente de trabalho. Indivíduos capacitados estão constantemente modificando as competências e adquirindo novas formas de agir, de pensar e de posicionar-se em sua atividade profissional. As competências individuais, continua o autor, nem sempre se referem a um fazer, mas a um saber fazer. Os melhores profissionais não são os que executam todas as atividades que lhes são designadas, mas são aqueles que se antecipam aos problemas e que buscam alternativas para resolvê-los.

Com base nas definições acima, responda às seguintes questões:

1. Fale sobre a Setur (missão, objetivos estratégicos, visão, características).

2. Para alcançar a missão da organização, quais as principais atividades desenvolvidas pelos profissionais formuladores de políticas públicas, que atuam na Secretaria?

3. Quais os desafios a serem enfrentados por estes profissionais?

4. Que competências organizacionais você julga relevantes para a consecução dos objetivos da Setur? (a organização deve ser capaz de quê?).

5. Para que a Setur consiga concretizar sua estratégia, o que os profissionais devem conhecer, saber fazer e ter atitude para fazer? 


\section{APÊNDICE II}

UNIVERSIDADE DE BRASÍLIA - UNB

Faculdade de EConomia, Administração, Contabilidade E CiênCia da informaÇão e documentaÇão - FACE

Programa de Pós-Graduação em Administração - PPGA

Curso Especialização em Gestão de Pessoas

\section{IDENTIFICAÇÃO DE COMPETÊNCIAS NECESSÁRIAS AOS PROFISSIONAIS FORMULADORES DE POLÍTICAS PÚBLICAS DA SECRETARIA DE TURISMO DE PERNAMBUCO}

A presente pesquisa está sendo desenvolvida por Fernanda Carneiro de Andrade Lima para cumprir uma exigência do curso de pós-graduação Lato Sensu em Gestão de Pessoas da Universidade de Brasília - UnB e objetiva identificar as competências necessárias aos formuladores de políticas públicas, bem como verificar o grau de importância e o grau de domínio das competências que estes profissionais possuem com relação às atividades realizadas na Secretaria de Turismo de Pernambuco. Para tanto, solicitamos que respondam o questionário abaixo apresentado.

Ressaltamos que a referida pesquisa possui o caráter puramente acadêmico e que os dados e as respostas aqui coletados serão tratados de modo a permitir o tratamento sigiloso das informações.

Por fim, agradecemos a colaboração de todos.

\section{ORIENTAÇÕES}

Por favor, considerando os atuais objetivos estratégicos da Secretaria de Turismo de Pernambuco, assinale um número de um a cinco, a fim de indicar o quão importante você considera cada uma das competências a seguir relacionadas. Lembre-se de que quanto mais próximo do número um você se posicionar, menor o grau de importância e menor o domínio da competência; quanto mais próximo do número cinco, maior o grau de importância e maior o domínio da competência.

ESCALA DE IMPORTÂNCIA

\begin{tabular}{|c|c|c|c|}
\hline 0 & 1 & 2 & 3 \\
\hline $\begin{array}{c}\text { Sem } \\
\text { importância }\end{array}$ & $\begin{array}{c}\text { Pouco } \\
\text { importante }\end{array}$ & Importante & $\begin{array}{c}\text { Muito } \\
\text { importante }\end{array}$ \\
\hline
\end{tabular}


ESCALA DE DOMÍNIO

\begin{tabular}{|c|c|c|c|}
\hline 0 & 1 & 2 & 3 \\
\hline $\begin{array}{c}\text { Não } \\
\text { domino }\end{array}$ & $\begin{array}{c}\text { Possuo } \\
\text { pouco } \\
\text { domínio }\end{array}$ & $\begin{array}{c}\text { Possuo } \\
\text { domínio quase } \\
\text { completo }\end{array}$ & $\begin{array}{c}\text { Domino } \\
\text { completamente }\end{array}$ \\
\hline
\end{tabular}

\begin{tabular}{|c|c|c|c|c|c|c|c|c|}
\hline \multirow{2}{*}{ Ter conhecimento de } & \multicolumn{4}{|c|}{ IMPORTÂNCIA } & \multicolumn{4}{|c|}{ DOMÍNIO } \\
\hline & 0 & 1 & 2 & 3 & 0 & 1 & 2 & 3 \\
\hline \multicolumn{9}{|l|}{$\begin{array}{l}\text { Valores, objetivos, missão, } \\
\text { planejamento estratégico da } \\
\text { Setur }\end{array}$} \\
\hline \multicolumn{8}{|l|}{ Atribuições da Setur } & \\
\hline \multicolumn{9}{|l|}{ Limites de atuação da Setur } \\
\hline \multicolumn{9}{|l|}{$\begin{array}{l}\text { Limite de atuação individual } \\
\text { (seu papel dentro da Setur) }\end{array}$} \\
\hline \multicolumn{9}{|l|}{$\begin{array}{l}\text { Legislação relativa à atividade } \\
\text { turística, aplicável às atividades } \\
\text { desenvolvidas }\end{array}$} \\
\hline \multicolumn{9}{|l|}{$\begin{array}{c}\text { Preparo de projetos turísticos } \\
\text { em conformidade com a } \\
\text { legislação referente à } \\
\text { Administração Pública }\end{array}$} \\
\hline \multicolumn{9}{|l|}{$\begin{array}{c}\text { Execução de projetos } \\
\text { turísticos em conformidade } \\
\text { com a legislação referente à } \\
\text { Administração Pública }\end{array}$} \\
\hline \multicolumn{9}{|l|}{$\begin{array}{l}\text { Aspectos teóricos relativos à } \\
\text { atividade turística }\end{array}$} \\
\hline \multicolumn{9}{|l|}{$\begin{array}{c}\text { Aspectos práticos relativos ao } \\
\text { turismo }\end{array}$} \\
\hline \multicolumn{9}{|l|}{$\begin{array}{l}\text { Técnicas de elaboração de } \\
\text { projetos turísticos }\end{array}$} \\
\hline $\begin{array}{l}\text { Técnicas de divulgação das } \\
\text { destinações turísticas }\end{array}$ & & & & & & & & \\
\hline
\end{tabular}




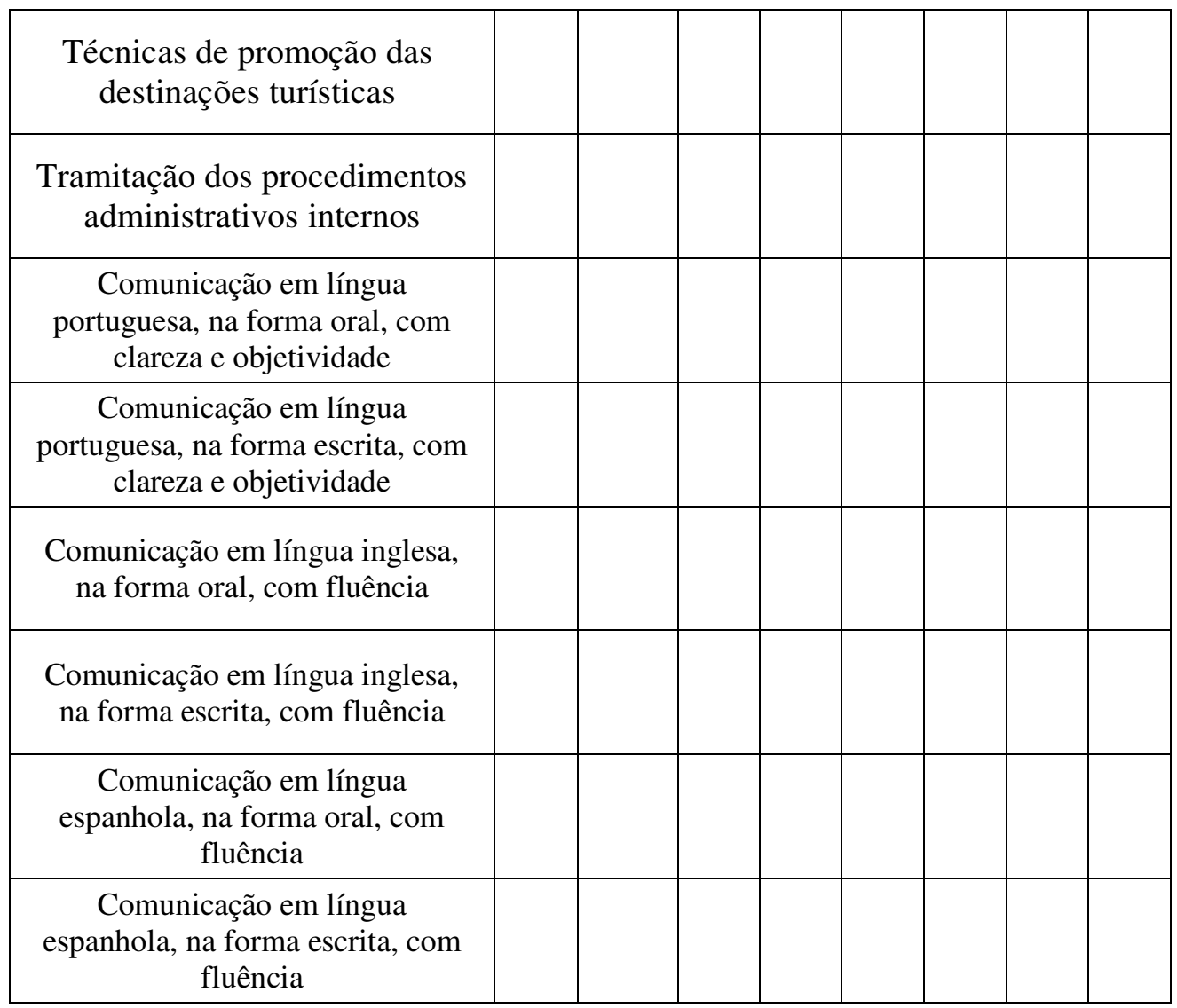

\begin{tabular}{|c|c|c|c|c|c|c|c|c|}
\hline \multirow{2}{*}{ Ter habilidade para } & \multicolumn{4}{|c|}{ IMPORTÂNCIA } & \multicolumn{4}{|c|}{ DOMÍNIO } \\
\hline & 0 & 1 & 2 & 3 & 0 & 1 & 2 & 3 \\
\hline $\begin{array}{l}\text { Reconhecer o turismo como } \\
\text { atividade interdependente, visto } \\
\text { que, para seu desenvolvimento, são } \\
\text { necessárias ações conjuntas com } \\
\text { outros segmentos da sociedade }\end{array}$ & & & & & & & & \\
\hline $\begin{array}{l}\text { Reconhecer a atividade turística } \\
\text { como global e local, } \\
\text { simultaneamente, tendo em vista } \\
\text { seu caráter dinâmico e suas } \\
\text { especificidades }\end{array}$ & & & & & & & & \\
\hline $\begin{array}{l}\text { Manter bons relacionamentos } \\
\text { interpessoais dentro da Setur }\end{array}$ & & & & & & & & \\
\hline $\begin{array}{c}\text { Manter bons relacionamentos } \\
\text { interpessoais no ambiente externo à } \\
\text { Setur }\end{array}$ & & & & & & & & \\
\hline
\end{tabular}




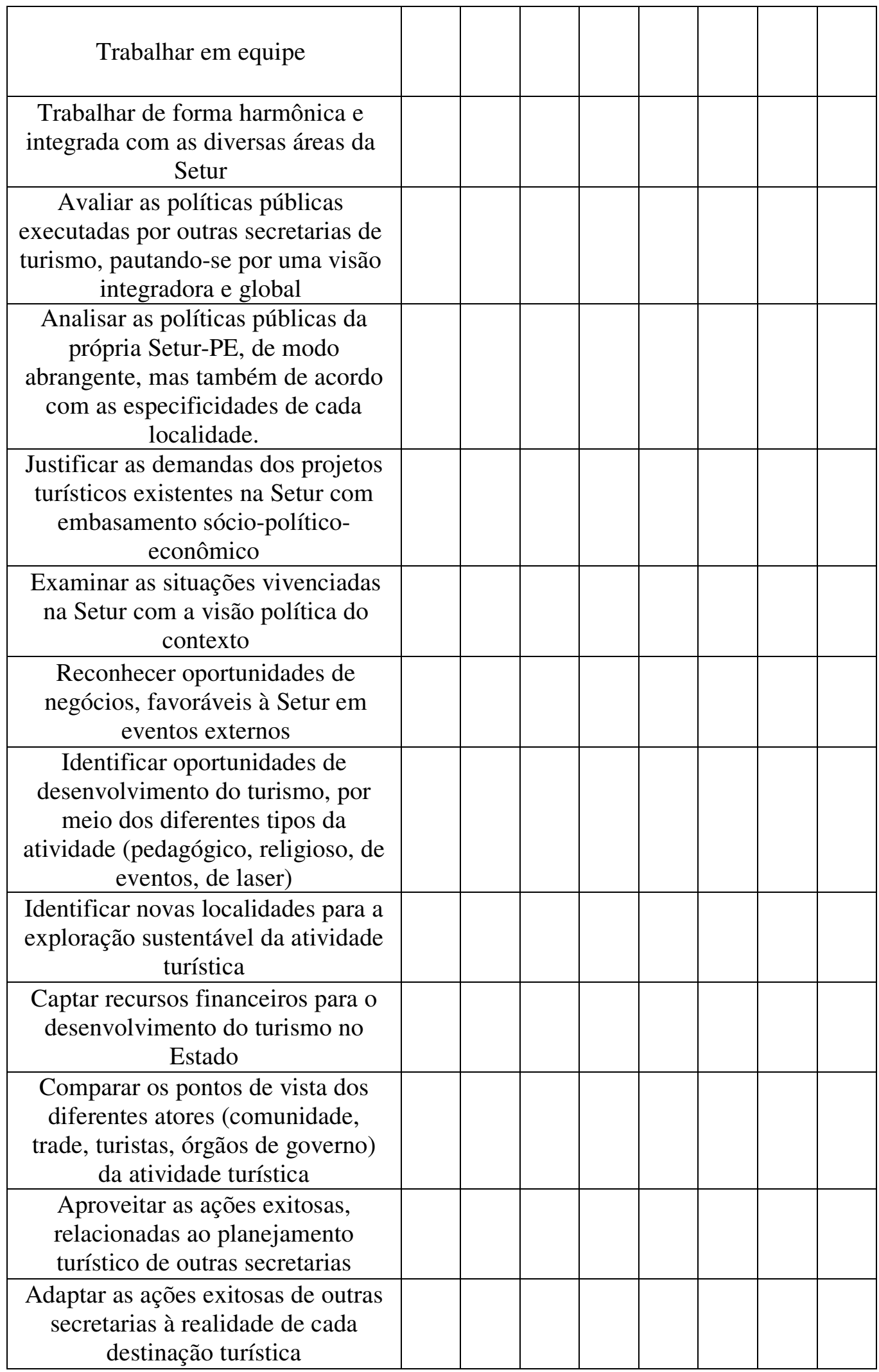




\begin{tabular}{|c|c|c|c|c|c|c|c|c|}
\hline \multirow{2}{*}{ Ter atitude para } & \multicolumn{4}{|c|}{ IMPORTÂNCIA } & \multicolumn{4}{|c|}{ DOMÍNIO } \\
\hline & $\mathbf{0}$ & 1 & 2 & 3 & $\mathbf{0}$ & 1 & 2 & 3 \\
\hline $\begin{array}{c}\text { Incluir a comunidade local, no } \\
\text { desenvolvimento dos projetos } \\
\text { turísticos }\end{array}$ & & & & & & & & \\
\hline $\begin{array}{l}\text { Integrar os diferentes pontos de } \\
\text { vista de diversos atores da atividade } \\
\text { turística (comunidade, trade, } \\
\text { turistas, órgãos de governo) }\end{array}$ & & & & & & & & \\
\hline $\begin{array}{c}\text { Identificar iniciativas que } \\
\text { maximizem os benefícios e } \\
\text { condições favoráveis, advindas da } \\
\text { atividade turística para os diversos } \\
\text { atores envolvidos no processo }\end{array}$ & & & & & & & & \\
\hline $\begin{array}{l}\text { Primar por escolher ações que } \\
\text { Minimizem os impactos ambientais } \\
\text { negativos, causados pelo turismo }\end{array}$ & & & & & & & & \\
\hline $\begin{array}{l}\text { Buscar ações que reduzam os } \\
\text { impactos culturais negativos, } \\
\text { trazidos pela atividade turística }\end{array}$ & & & & & & & & \\
\hline $\begin{array}{l}\text { Procurar mecanismos que atenuem } \\
\text { os impactos negativos sócio- } \\
\text { econômicos, em decorrência do } \\
\text { turismo }\end{array}$ & & & & & & & & \\
\hline $\begin{array}{l}\text { Realizar, periodicamente, pesquisas } \\
\text { com os atores da atividade }\end{array}$ & & & & & & & & \\
\hline $\begin{array}{c}\text { Divulgar o trabalho executado pela } \\
\text { Setur para os diferentes atores da } \\
\text { atividade }\end{array}$ & & & & & & & & \\
\hline $\begin{array}{c}\text { Atuar em conjunto com as demais } \\
\text { entidades, empresas e secretarias } \\
\text { (Educação, Segurança, Defesa } \\
\text { Social, Cultura e Meio Ambiente) } \\
\text { do Estado e do Brasil }\end{array}$ & & & & & & & & \\
\hline $\begin{array}{c}\text { Ser proativo diante das situações } \\
\text { vivenciadas na Setur }\end{array}$ & & & & & & & & \\
\hline $\begin{array}{l}\text { Atuar de forma ética, frente à } \\
\text { sociedade e ao meio-ambiente }\end{array}$ & & & & & & & & \\
\hline $\begin{array}{l}\text { Agir com responsabilidade, frente à } \\
\text { sociedade e ao meio-ambiente }\end{array}$ & & & & & & & & \\
\hline
\end{tabular}

